In cooperation with the Lockheed Martin Corporation

Polychlorinated Biphenyls in Suspended-Sediment Samples from Outfalls to Meandering Road Creek at Air Force Plant 4, Fort Worth, Texas, 2003-08

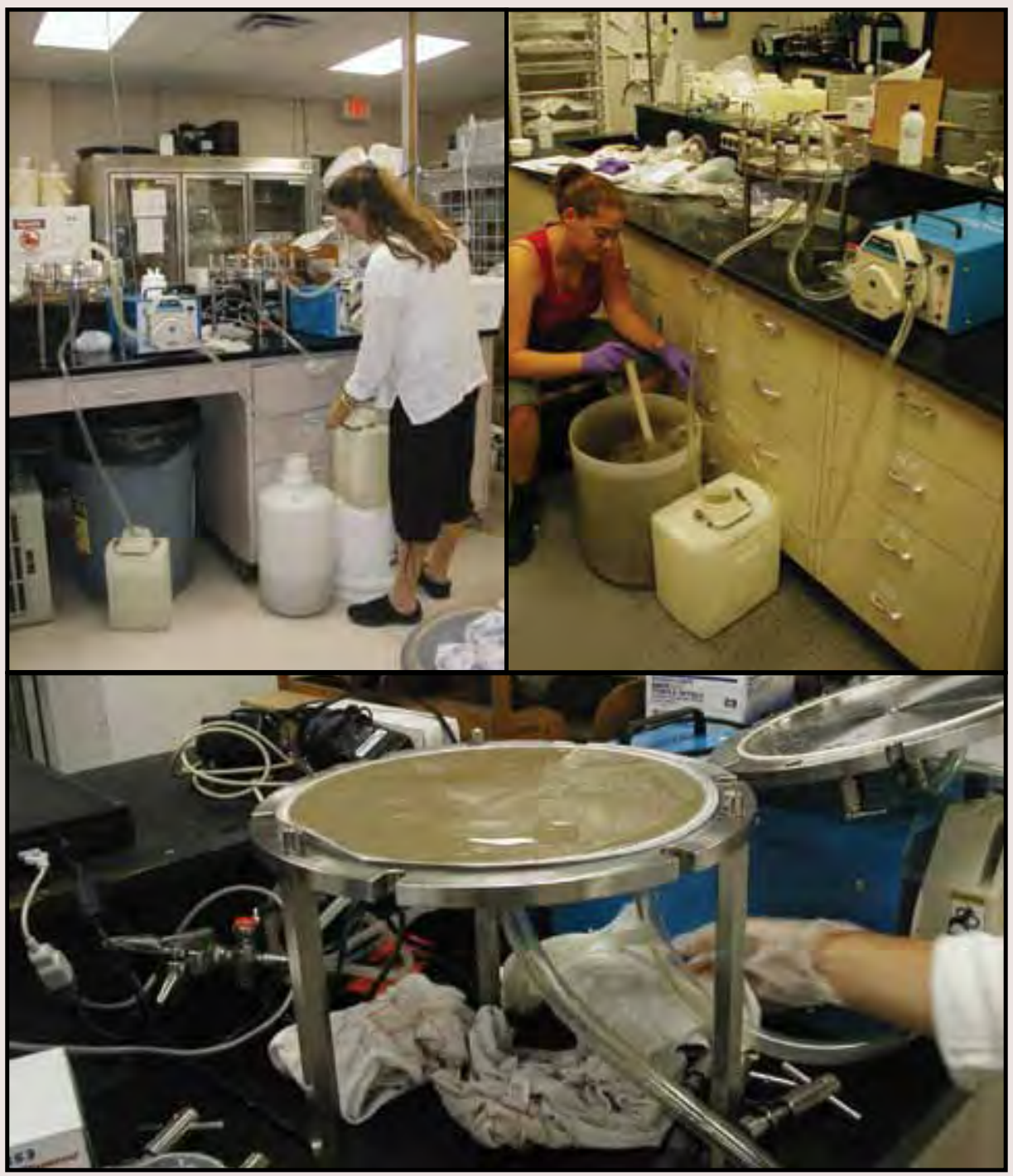

Scientific Investigations Report 2010-5076 


\section{Front cover:}

Top left, Pumping two suspended-sediment samples during filtration for organic analyses, 2006.

Top right, Churning and pumping a suspended-sediment sample during filtration for organic analyses, 2003.

Bottom, Filtering a suspended-sediment sample to isolate sediments for organic analyses, 2006. 


\section{Polychlorinated Biphenyls in Suspended- Sediment Samples from Outfalls to Meandering Road Creek at Air Force Plant 4, Fort Worth, Texas, 2003-08}

By Christopher L. Braun and Jennifer T. Wilson

In cooperation with the Lockheed Martin Corporation

Scientific Investigations Report 2010-5076 


\section{U.S. Department of the Interior \\ KEN SALAZAR, Secretary \\ U.S. Geological Survey \\ Marcia K. McNutt, Director}

U.S. Geological Survey, Reston, Virginia: 2010

This and other USGS information products are available at http://store.usgs.gov/
U.S. Geological Survey
Box 25286, Denver Federal Center
Denver, CO 80225
To learn about the USGS and its information products visit http://www.usgs.gov/
1-888-ASK-USGS

Any use of trade, product, or firm names is for descriptive purposes only and does not imply endorsement by the U.S. Government.

Although this report is in the public domain, permission must be secured from the individual copyright owners to reproduce any copyrighted materials contained within this report.

Suggested citation:

Braun, C.L., and Wilson, J.T., 2010, Polychlorinated biphenyls in suspended-sediment samples from outfalls to Meandering Road Creek at Air Force Plant 4, Fort Worth, Texas, 2003-08: U.S. Geological Survey Scientific Investigations Report 2010-5076, 20 p. 


\section{Acknowledgments}

The authors thank Lockheed Martin Corporation personnel at U.S. Air Force Plant 4 in Fort Worth, Texas, for providing access to the sampling sites. 
Blank Page 


\section{Contents}

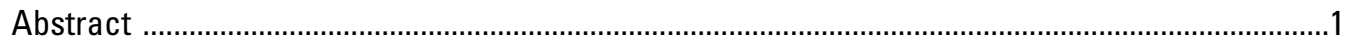

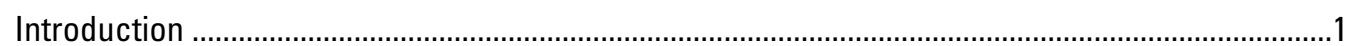

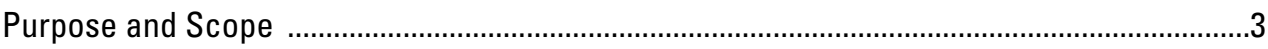

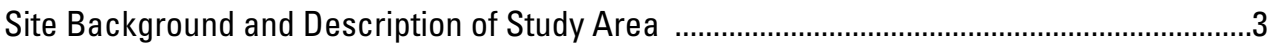

Polychlorinated Biphenyls ..........................................................................................

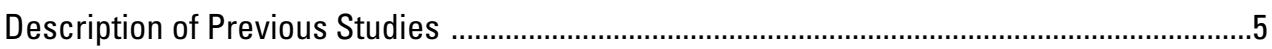

Engineering Controls Used to Alleviate Polychlorinated Biphenyl Contamination at

Air Force Plant 4 .......................................................................................................

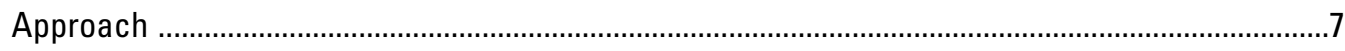

Collection and Processing of Suspended-Sediment Samples ..................................................

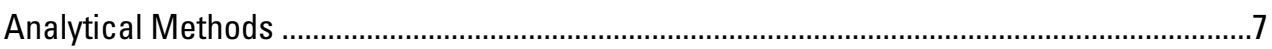

Quality Control .........................................................................................................................

Polychlorinated Biphenyls in Suspended-Sediment Samples from Outfalls to Meandering

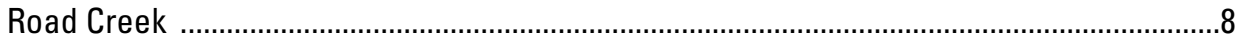

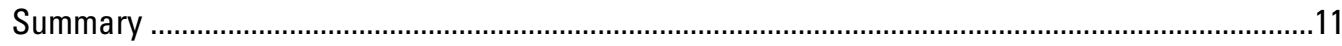

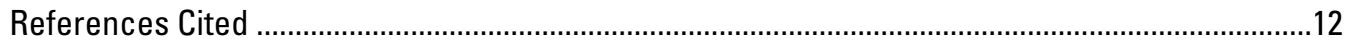

Appendixes

1. Concentrations of selected polychlorinated biphenyl congeners in suspendedsediment samples collected from outfalls 4 and 5, Air Force Plant 4, Fort Worth, Texas, 2003-07

2. Concentrations of antibacterial, antifungal, pesticide, and flame retardant compounds in suspended-sediment samples collected from outfalls 4 and 5, Air Force Plant 4, Fort Worth, Texas, 2008

\section{Figures}

1-2. Maps showing:

1. Location of Meandering Road Creek, Woods Inlet of Lake Worth, and Air Force Plant 4, Fort Worth, Texas

2. Suspended-sediment sampling sites, storm drainage areas for outfalls 4 and 5 , areas of known or suspected polychlorinated biphenyl (PCB) releases, former landfills, and areas where engineering controls (asphalt cap areas and sweeping) were implemented to potentially alleviate PCB contamination at Air Force Plant 4, Fort Worth, Texas, 2003-08

3-4. Graphs showing:

3. Ratios of total polychlorinated biphenyl (PCB) concentrations (sum of 18 reported congeners [ $\left.\Sigma P C B_{c}\right]$ ) to threshold effect concentration, a consensusbased sediment-quality guideline for PCBs, for suspended-sediment samples collected from outfalls 4 and 5, Air Force Plant 4, Fort Worth, Texas, 2003-08 ........9

4. Ratio of individual polychlorinated biphenyl (PCB) congener concentrations to sum of 10 selected PCB congeners for suspended-sediment samples collected from outfalls 4 and 5, Air Force Plant 4, Fort Worth, Texas, 2003-08 ......10 


\section{Table}

1. Concentrations of polychlorinated biphenyls in suspended-sediment samples collected from outfalls 4 and 5, Air Force Plant 4, Fort Worth, Texas, 2008

\section{Conversion Factors, Datum, and Sediment-Quality Units}

\section{SI to Inch/Pound}

\begin{tabular}{lcl}
\hline \multicolumn{1}{c}{ Multiply } & By & \multicolumn{1}{c}{ To obtain } \\
\hline centimeter $(\mathrm{cm})$ & Length & \\
kilometer $(\mathrm{km})$ & 0.3937 & inch (in.) \\
meter $(\mathrm{m})$ & 0.6214 & mile $(\mathrm{mi})$ \\
\hline & 3.281 & foot $(\mathrm{ft})$ \\
\hline square meter $\left(\mathrm{m}^{2}\right)$ & Area & \\
\hline & 10.76 & square foot $\left(\mathrm{ft}^{2}\right)$ \\
\hline liter $(\mathrm{L})$ & Volume & \\
\hline & 33.82 & ounce, fluid $(\mathrm{fl} . \mathrm{oz})$ \\
\hline gram $(\mathrm{g})$ & Mass & \\
\hline & 0.03527 & ounce, avoirdupois $(\mathrm{oz})$ \\
\hline kilopascal $(\mathrm{kPa})$ & Pressure & pound per square inch $\left(\mathrm{lb} / \mathrm{in}^{2}\right)$ \\
\hline
\end{tabular}

Temperature in degrees Celsius $\left({ }^{\circ} \mathrm{C}\right)$ may be converted to degrees Fahrenheit $\left({ }^{\circ} \mathrm{F}\right)$ as follows:

$$
{ }^{\circ} \mathrm{F}=\left(1.8 x^{\circ} \mathrm{C}\right)+32
$$

\section{Datum}

Horizontal coordinate information is referenced to the North American Datum of 1983 (NAD 83).

\section{Sediment-Quality Units}

Chemical compound concentrations are reported in micrograms per kilogram $(\mu \mathrm{g} / \mathrm{kg})$, a unit expressing the concentration of a chemical compound as weight (micrograms) per unit volume (kilogram) of sediment. 


\title{
Polychlorinated Biphenyls in Suspended-Sediment Samples from Outfalls to Meandering Road Creek at Air Force Plant 4, Fort Worth, Texas, 2003-08
}

\author{
By Christopher L. Braun and Jennifer T. Wilson
}

\section{Abstract}

Meandering Road Creek is an intermittent stream and tributary to Lake Worth, a reservoir on the West Fork Trinity River on the western edge of Fort Worth, Texas. U.S. Air Force Plant 4 (AFP4) is on the eastern shore of Woods Inlet, an arm of Lake Worth. Meandering Road Creek gains inflow from several stormwater outfalls as it flows across AFP4.

Several studies have characterized polychlorinated biphenyls (PCBs) in the water and sediments of Lake Worth and Meandering Road Creek; sources of PCBs are believed to originate primarily from AFP4. Two previous U.S. Geological Survey (USGS) reports documented elevated PCB concentrations in surficial sediment samples from Woods Inlet relative to concentrations in surficial sediment samples from other parts of Lake Worth. The second of these two previous reports also identified some of the sources of PCBs to Lake Worth. These reports were followed by a third USGS report that documented the extent of PCB contamination in Meandering Road Creek and Woods Inlet and identified runoff from outfalls 4 and 5 at AFP4 as prominent sources of these PCBs.

This report describes the results of a fourth study by the USGS, in cooperation with the Lockheed Martin Corporation, to investigate PCBs in suspended-sediment samples in storm runoff from outfalls 4 and 5 at AFP4 following the implementation of engineering controls designed to potentially alleviate PCB contamination in the drainage areas of these outfalls. Suspended-sediment samples collected from outfalls 4 and 5 during storms on March 2 and November 10, 2008, were analyzed for selected PCBs. Sums of concentrations of 18 reported $\mathrm{PCB}$ congeners $\left(\sum \mathrm{PCB}_{\mathrm{c}}\right)$ in suspended-sediment samples collected before and after implementation of engineering controls are compared. At both outfalls, the $\sum \mathrm{PCB}_{\mathrm{c}}$ before engineering controls was higher than the $\sum \mathrm{PCB}_{\mathrm{c}}$ after engineering controls. The $\Sigma \mathrm{PCB}_{\mathrm{c}}$ in suspended-sediment samples collected at AFP4 before and after implementation of engineering controls also is compared to the threshold effect concentration (TEC), the concentration below which adverse effects to benthic biota rarely occur. $\Sigma \mathrm{PCB}_{\mathrm{c}}$ exceeded the TEC for 75 percent of the samples collected at outfall 4 and 67 percent of the samples collected at outfall 5 before the implementation of engineering controls. $\sum \mathrm{PCB}_{\mathrm{c}} \mathrm{did}$ not exceed the TEC in samples collected at either outfall 4 or outfall 5 after the implementation of engineering controls.

The relative prominence of 10 selected PCB congeners was evaluated by graphical analysis of ratios of individual concentrations of the $10 \mathrm{PCB}$ congeners to the sum of these PCB congeners. An overall decrease in concentrations of PCB congeners at outfalls 4 and 5 after implementation of engineering controls, as well as a shift in prominence from lighter, less chlorinated congeners to a heavier, more chlorinated congener might have resulted from the implementation of engineering controls. Because of the small number of samples collected and lack of runoff and precipitation data to evaluate comparability of sampling conditions before and after implementation of engineering controls, all conclusions are preliminary.

\section{Introduction}

Meandering Road Creek is an intermittent stream and tributary to Lake Worth, a reservoir on the West Fork Trinity River on the western edge of Fort Worth, Tex. U.S. Air Force Plant 4 (AFP4) is on the eastern shore of Woods Inlet, an arm of Lake Worth that extends south from the main body of the lake, east of Interstate Highway 820 (fig. 1). Meandering Road Creek gains inflow from several stormwater outfalls on AFP4 as the creek flows to its terminus at Woods Inlet. Because of groundwater contamination, AFP4 was placed on the National Priorities List of hazardous waste sites in 1990 (U.S. Environmental Protection Agency, 1990). In spring 2000, the Texas Department of Health issued a fish consumption advisory for Lake Worth because of elevated concentrations of polychlorinated biphenyls (PCBs) in the edible tissues of selected species of fish (Texas Department of State Health Services, 2010). PCBs are hydrophobic organic contaminants that sorb strongly to organic matter and particulates; detection of PCBs is common in urban lake and reservoir sediments (Van Metre, Callender, and Fuller, 1997; Van Metre and others, 1998; Long and others, 2003). The occurrence of PCBs in fish led to several investigations by the U.S. Geological Survey (USGS) in cooperation with the U.S. Air Force to 


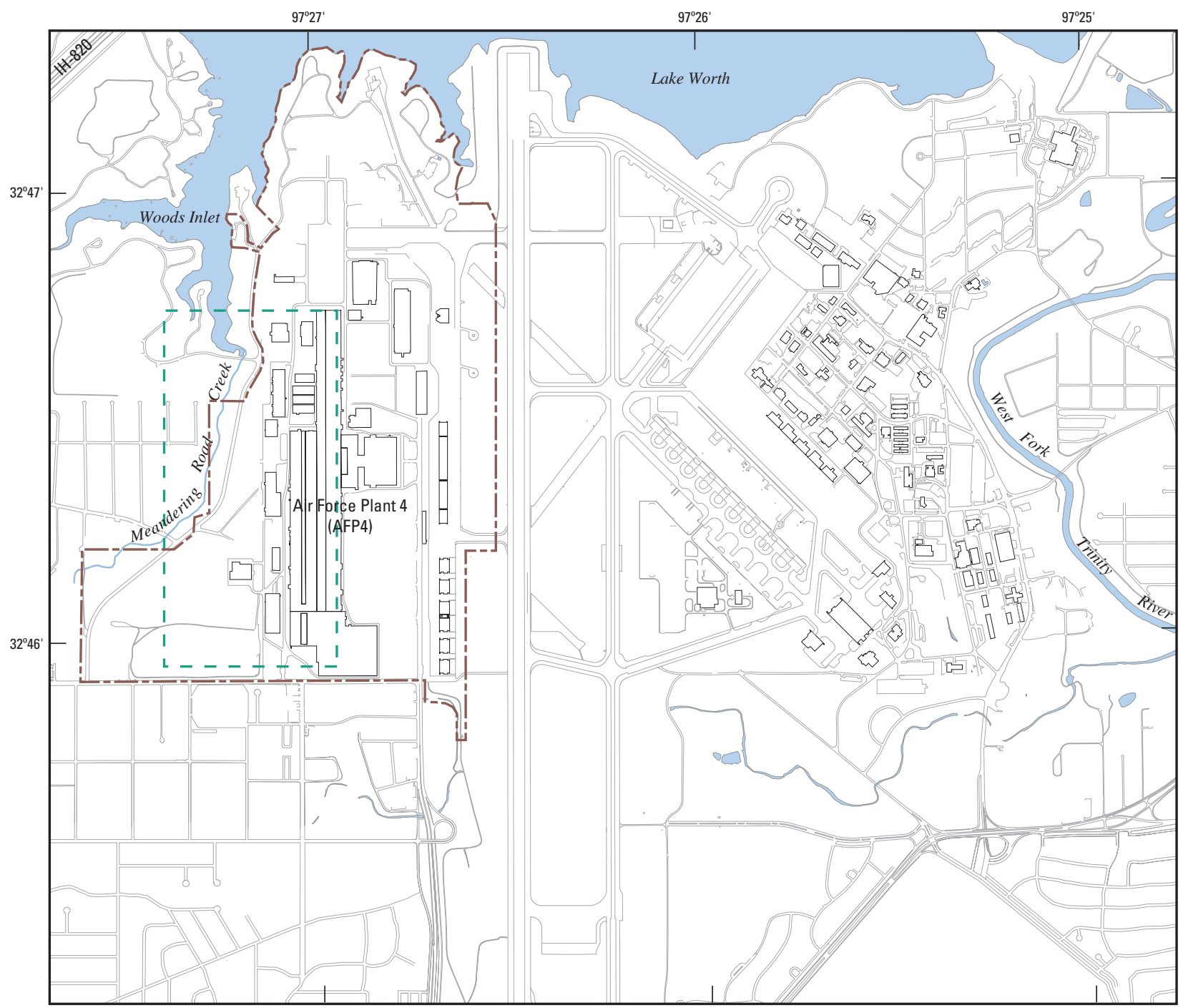

Base from U.S. Air Force, Aeronautical Systems Center

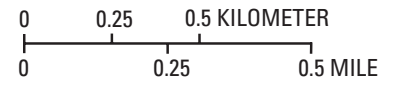

EXPLANATION

--- AFP4 boundary

- - - Boundary of are shown in figure2
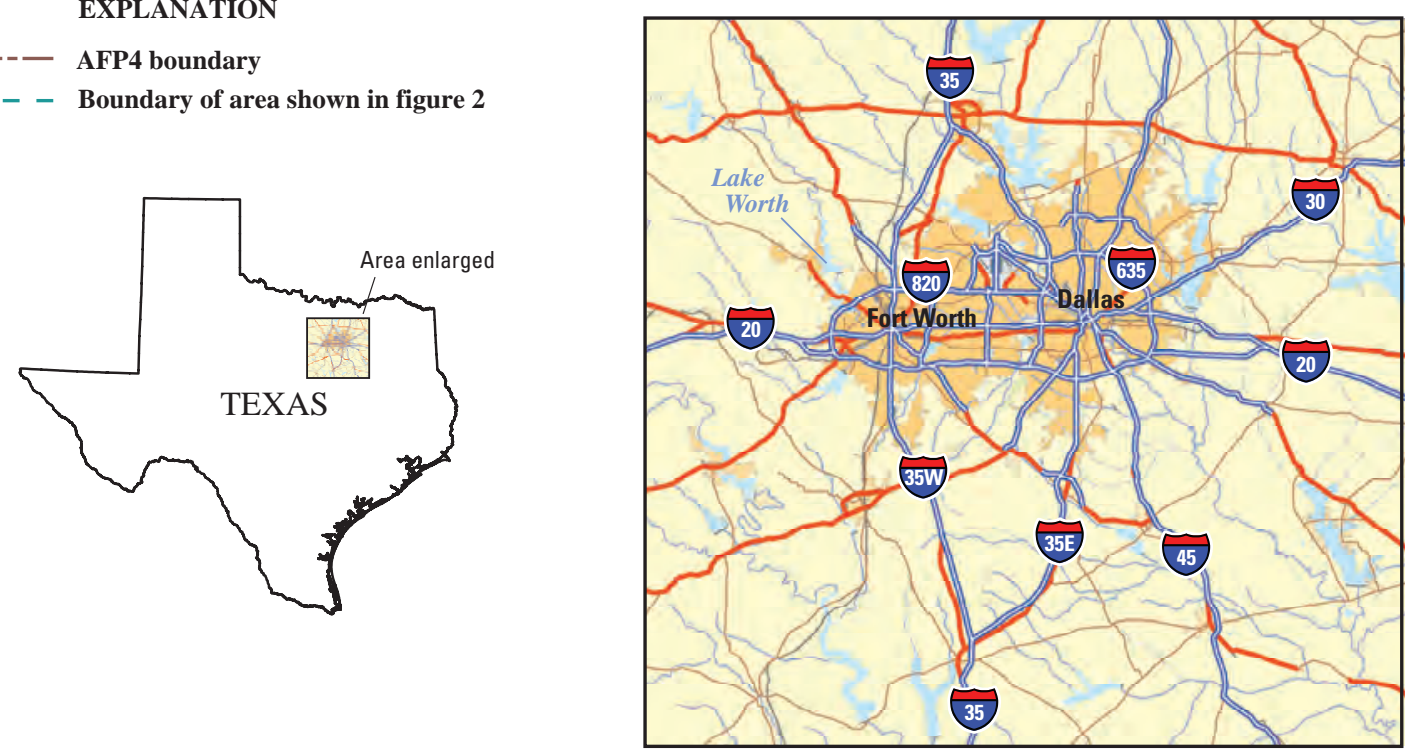

Figure 1. Location of Meandering Road Creek, Woods Inlet of Lake Worth, and Air Force Plant 4, Fort Worth, Texas. 
characterize sediment-associated contaminants, including PCBs, in the lake-bottom, streambed, and suspended sediments of Lake Worth, Woods Inlet, Meandering Road Creek, and the stormwater outfalls at AFP4 that drain to Meandering Road Creek (Harwell and others, 2003; Besse and others, 2005; Braun and others, 2008). Selected PCBs were analyzed in lake-bottom sediment samples collected from Lake Worth and in streambed and suspended-sediment samples collected from Meandering Road Creek (a tributary to Lake Worth) at AFP4 and from outfalls that drain to Meandering Road Creek. On the basis of PCB concentrations measured in suspended-sediment samples, outfalls 4 and 5 at AFP4 were identified as two prominent sources of PCBs in Meandering Road Creek (Braun and others, 2008). Engineering controls were implemented in late 2007 and early 2008, from about November 2007 through February 2008, to potentially alleviate PCB contamination in the drainage areas of outfalls 4 and 5. This report, the fourth USGS study, was done in cooperation with the Lockheed Martin Corporation. The study investigated the concentration of PCBs in suspendedsediment samples in storm runoff from outfalls 4 and 5 at AFP4 following the implementation of engineering controls in the drainage areas of these outfalls and compared the measured concentrations to results from previous USGS studies at the site and to applicable threshold effect concentration (TEC) guidelines.

\section{Purpose and Scope}

This report describes concentrations of PCB congeners measured in suspended-sediment samples collected from outfalls 4 and 5 at AFP4 during 2003-08. PCB concentrations measured in suspended-sediment samples collected from outfalls 4 and 5 during 2003-07 for previous USGS studies at AFP4, before implementation of engineering controls designed to potentially alleviate PCB contamination in the drainage areas of outfalls 4 and 5, are compared to PCB concentrations measured in suspended-sediment samples collected from outfalls 4 and 5 during periods of runoff on March 2 and November 10, 2008, after implementation of engineering controls.

Concentrations of PCB congeners are compared to TECs described in consensus-based sediment-quality guidelines. Concentrations of PCB congeners were normalized to compare relative distributions of $\mathrm{PCB}$ congeners from the different samples. In this report, a subset of 18 of the 27 PCB congeners that were analyzed in samples collected from outfalls 4 and 5 in previous USGS studies at AFP4 were quantified and compared to the same 18 PCB congeners quantified in samples collected in 2008. The relative prominence of lighter and heavier (more and less volatile, respectively) PCB congeners before and after implementation of engineering controls are also described. The limited scope of the project did not include measuring the discharge of Meandering Road Creek or precipitation associated with each storm, which limits the comparability of samples collected during different storms. Because of the small number of samples collected and lack of runoff and precipitation data to evaluate comparability of sampling conditions before and after implementation of engineering controls, all conclusions are preliminary.

\section{Site Background and Description of Study Area}

AFP4 has manufactured military aircraft since 1942 on land adjacent to Woods Inlet of Lake Worth in Fort Worth and is currently (2009) in the remedial action phase of the Superfund process (U.S. Environmental Protection Agency, 2009). Waste materials containing PCBs were generated at the plant and likely placed in on-site landfills or burned in fire-training exercises prior to 1973 (Texas Department of Health, 1998). Areas of known and suspected PCB releases are described in detail in Braun and others (2008), including a transformer failure in March 1984 in an electrical substation, which resulted in the leakage of PCBs adjacent to building 14 (fig. 2; area 014PCBLK3). Surface-water runoff from the area near the PCB leak at building 14 either discharges to Meandering Road Creek at outfall 4 or collects in a storm-sewer line that ultimately discharges to Meandering Road Creek at outfall 4 (fig. 2). In March 1989, PCBs were discovered to have leaked beneath a concrete slab inside building 5 (fig. 2; area 005PCBLK1). Storm-sewer lines intersecting the PCB leak at building 5 discharge to outfalls 4 and 5 (fig. 2). PCBs also might have been released from Fire Department Training Area 2 (FDTA2), a 15-meter-diameter earthen ring (RUST Geotech, 1995) west of building 15 used for semiannual fire training exercises between 1955 and 1965; FDTA2 might have been used for disposal of waste oils and fuels containing PCBs (CH2M Hill, 1984). FDTA2 is next to a storm-sewer line that discharges to Meandering Road Creek at outfall 4. Some of the surface-water runoff from FDTA2 collects in a storm-sewer line that eventually discharges to Meandering Road Creek at outfall 4. Because FDTA2 is in the drainage area of outfall 5 , the rest of the runoff from FDTA2 discharges to Meandering Road Creek at outfall 5 .

Historical landfills 1 and 3 on opposite sides of Bomber Road (fig. 2) are another suspected source of PCB releases. These landfills were used to dispose of potentially hazardous wastes including used oils, solvents, thinners, paint, and unspecified liquid waste (International Technology Corporation, 2001). In 1966, landfill 1 was closed, and the area was graded and paved to make the west parking lot (fig. 2). Landfill 3 is on the east bank of Meandering Road Creek on the west side of Bomber Road (fig. 2). Landfills 1 and 3 provide surface-water runoff and groundwater seepage to Meandering Road Creek; remediation work to curtail runoff and groundwater seepage from these landfills began in the 1980s and is 


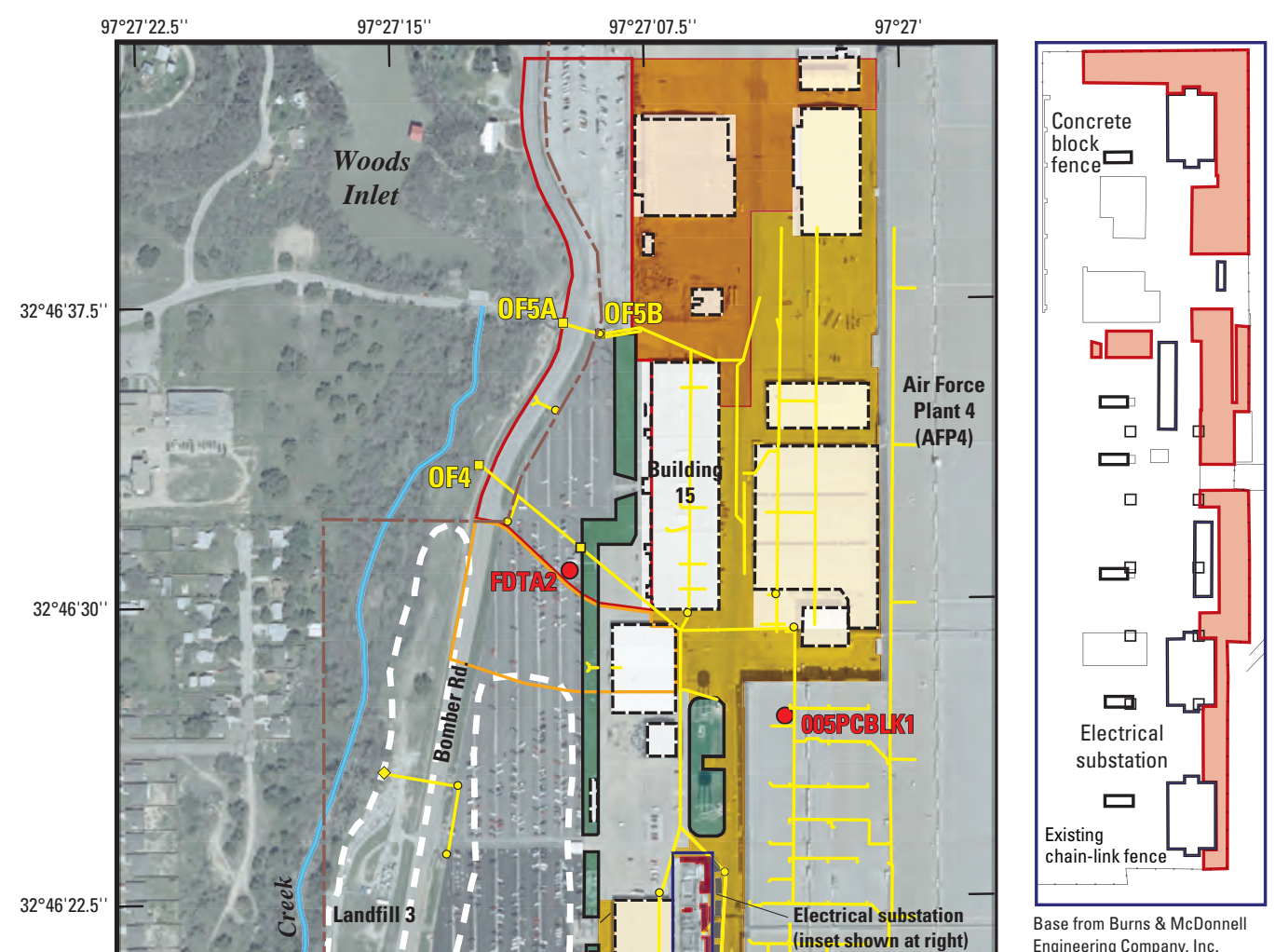

Base from Burns \& McDonn

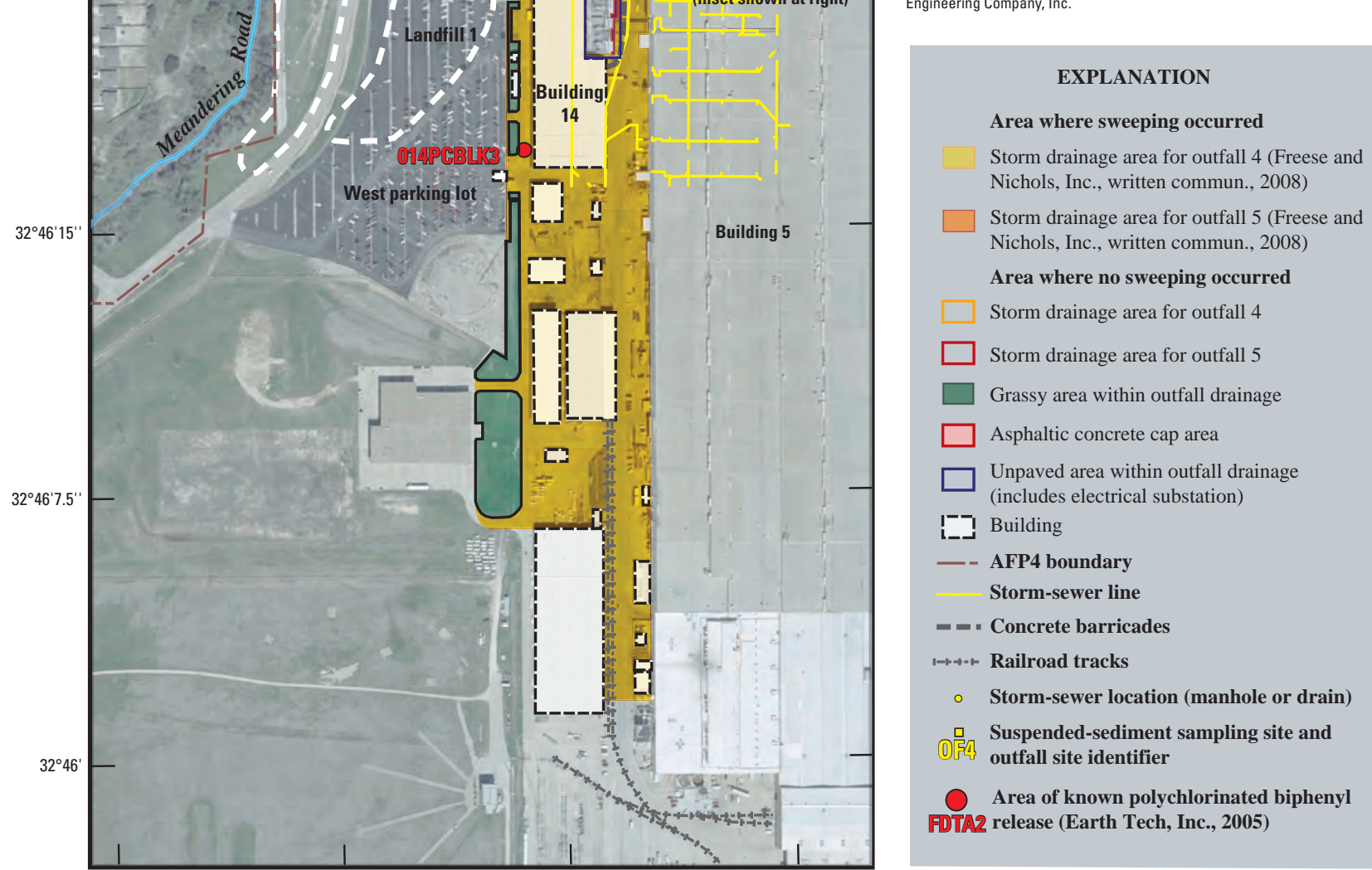

Base modified from U.S. Geological Survey

Digital orthophoto quarter-quadrangle,

Universal Transverse Mercator projection, Zone 14

North American Datum of 1983, 0.3-meter resolution

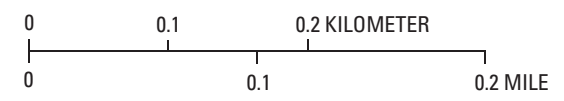

Figure 2. Suspended-sediment sampling sites, storm drainage areas for outfalls 4 and 5 , areas of known or suspected polychlorinated biphenyl (PCB) releases, former landfills, and areas where engineering controls (asphalt cap areas and sweeping) were implemented to potentially alleviate PCB contamination at Air Force Plant 4, Fort Worth, Texas, 2003-08. 
described in detail in Braun and others (2008). Meandering Road Creek borders AFP4 to the west and flows north to the Woods Inlet of Lake Worth. Historically, Meandering Road Creek received contaminated runoff from stormwater outfalls 4 and 5 (Besse and others, 2005; Braun and others, 2008). Outfall 4 receives runoff from several buildings and parking areas, including some of the area over landfill 1, and drains into Meandering Road Creek about 200 meters upstream from the point where Meandering Road Creek enters Woods Inlet. Outfall 5 receives runoff from building 15 and parking areas and drains into Meandering Road Creek about 25 meters upstream from the point where Meandering Road Creek enters Woods Inlet (fig. 2). Additional site background information, including a more detailed history of PCB contamination studies at AFP4, is provided in Braun and others (2008).

\section{Polychlorinated Biphenyls}

PCBs are comprised of as many as 209 theoretically possible chlorinated compounds, called congeners, with various numbers and positions of chlorine atoms attached to the biphenyl structure. Each congener has been assigned a congener number; congener number increases generally with increasing chlorination of the biphenyl structure. Of the 209 theoretically possible congeners, about 130 were widely used in commercial PCB mixtures (Erickson, 2001). Braun and others (2008) summarizes the development and use of PCBs and their adverse human health effects and association with cancer in humans and animals.

In the samples collected for this study, the USGS National Water Quality Laboratory (NWQL), Denver, Colo., quantified 18 common PCB congeners of the 27 common PCB congeners quantified in Braun and others (2008). Total PCBs were calculated as the sum of the 18 quantified congeners $\left(\sum \mathrm{PCB}_{\mathrm{c}}\right)$. Consistent with the treatment of nondetections of PCB congeners in previous USGS studies at AFP4 (Harwell and others, 2003; Besse and others, 2005; Braun and others, 2008), nondetections of PCB congeners were treated as zeros; estimated concentrations were used at their reported values. Detection frequencies for the 18 PCB congeners analyzed in this report varied by the degree of chlorination; in general, detection frequency increased with increasing degree of chlorination (table 1).

Concentrations of total PCBs in suspended-sediment samples are compared to a consensus-based sedimentquality guideline developed for freshwater ecosystems by MacDonald and others (2000) to provide a general indication of the degree of contamination. The TEC (table 1) is the concentration below which adverse effects to benthic biota rarely occur (MacDonald and others, 2000). This sedimentquality guideline was derived through various laboratory, field, and theoretical methods and is neither definitive for determining sediment toxicity to benthic biota nor to be extrapolated to assess adverse effects to fish, aquatic plants, or humans (Long and others, 1995; MacDonald and others,
2000). Although this sediment-quality guideline provides a general indication of the degree of contamination, it does not provide a benchmark for concern for accumulation in fish or for human health risk associated with eating fish.

\section{Description of Previous Studies}

A Preliminary Assessment/Site Inspection (PA/SI) and a Remedial Investigation/Feasibility Study (RI/FS) of the AFP4 site began in October 1990 to characterize contamination of Lake Worth and its tributaries by PCBs and other organic contaminants (Braun and others, 2008), as well as to accomplish other objectives. Elevated concentrations of contaminants, such as PCBs, were detected in a small, inedible fish species (mosquitofish) during the PA/SI in July 1998. One conclusion of the PA/SI in July 1998 was that an indeterminate public health hazard existed in Lake Worth from exposure to contaminants through the food chain (Texas Department of Health, 1998). The Texas Department of Health (TDH) issued a fish-consumption advisory following fish sampling by the USGS (Moring, 2002) because the levels of PCBs detected in edible fish samples posed a "significant health risk" (Texas Department of State Health Services, 2010). A detailed description of the July 1998 TDH site evaluation and the Agency for Toxic Substances and Disease Registry (2001) site evaluation is provided in Moring (2002). The detection of PCBs and other organic contaminants in fish collected from Lake Worth and its tributaries led to three subsequent studies by the USGS in cooperation with the U.S. Air Force. In the first study, Lake Worth lake-bottom sediment samples were collected during 2000-2001 and analyzed for sedimentassociated contaminants, including PCBs (Harwell and others, 2003). That study documented elevated PCB concentrations in surficial sediment in Woods Inlet relative to concentrations in surficial sediment in other parts of Lake Worth. This finding indicated that the Woods Inlet watershed likely contained a source, or sources, of PCBs. In 2003, a second USGS study to further characterize elevated PCB concentrations in sediment in Woods Inlet mapped the distribution of elevated PCB concentrations in Woods Inlet and identified possible source areas of PCBs in the watershed of Woods Inlet (Besse and others, 2005). The findings of that report indicated that the highest PCB concentrations were near the mouth of Meandering Road Creek and that PCBs originate in the Meandering Road Creek watershed. Furthermore, total PCB concentrations in suspended and streambed sediment indicated storm drain outfall 4, which receives runoff from AFP4, was a likely source of PCBs to Meandering Road Creek and ultimately Woods Inlet. However, the study did not determine whether outfall 4 was the only source of PCBs to Meandering Road Creek and Woods Inlet. Results from these studies (Harwell and others, 2003; Besse and others, 2005) prompted a third study by the USGS. During 2004-07, the USGS investigated the degree of PCB contamination of Meandering Road Creek and Woods Inlet and attempted to identify possible sources of PCBs to 
Table 1. Concentrations of polychlorinated biphenyls in suspended-sediment samples collected from outfalls 4 and 5 , Air Force Plant 4 , Fort Worth, Texas, 2008.

[In micrograms per kilogram except as noted; PCB, polychlorinated biphenyl; OF4, outfall 4; <, nondetection less than minimum reporting level; E, estimated; OF5, outfall 5; - -, not available; $\Sigma \mathrm{PCB}_{c}$, sum of $18 \mathrm{PCB}$ congeners]

\begin{tabular}{lllllllllllll}
\hline $\begin{array}{c}\text { U.S. Geological } \\
\begin{array}{c}\text { Survey station } \\
\text { number }\end{array}\end{array}$ & $\begin{array}{c}\text { identifier } \\
\text { (fig. 2) }\end{array}$ & Sample date & $\begin{array}{c}\text { Set } \\
\text { num- } \\
\text { ber }\end{array}$ & $\begin{array}{c}\text { PCB } \\
\mathbf{4 9}\end{array}$ & $\begin{array}{c}\text { PCB } \\
\mathbf{5 2}\end{array}$ & $\begin{array}{c}\text { PCB } \\
\mathbf{7 0}\end{array}$ & $\begin{array}{c}\text { PCB } \\
\mathbf{1 0 1}\end{array}$ & $\begin{array}{c}\text { PCB } \\
\mathbf{1 1 0}\end{array}$ & $\begin{array}{c}\text { PCB } \\
\mathbf{1 1 8}\end{array}$ & $\begin{array}{c}\text { PCB } \\
\mathbf{1 3 8}\end{array}$ & $\begin{array}{c}\text { PCB } \\
\mathbf{1 4 6}\end{array}$ & $\begin{array}{c}\text { PCB } \\
\mathbf{1 4 9}\end{array}$ \\
\hline 08045359 & OF4 & $3 / 2 / 2008$ & 002 & $<1.0$ & $<1.0$ & $<1.0$ & $<1.0$ & 3.8 & 1.6 & 3.7 & 0.54 & 3.0 \\
08045359 & OF4 & $11 / 10 / 2008$ & 116 & $<1.0$ & $<1.0$ & $<1.0$ & $<1.0$ & $<1.0$ & $<.1$ & 1.1 & .62 & 3.2 \\
08045359 & OF4 duplicate & $11 / 10 / 2008$ & 116 & $<1.0$ & $<1.0$ & $<1.0$ & $<1.0$ & $<1.0$ & $<.1$ & .90 & .38 & 2.8 \\
& & & & & & & & & & & & \\
324638097270901 & OF5A & $3 / 2 / 2008$ & 002 & $<1.0$ & $<1.0$ & $<1.0$ & $<1.0$ & E.67 & .48 & 1.4 & .23 & 1.7 \\
324638097270901 & OF5A & $11 / 10 / 2008$ & 116 & $<1.0$ & $<1.0$ & $<1.0$ & $<1.0$ & $<1.0$ & .65 & 1.2 & .25 & 4.1
\end{tabular}

Sediment-quality guidelines:

Threshold effect concentration (TEC) ${ }^{1}$

Minimum reporting level (MRL)

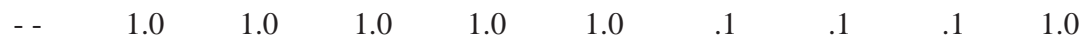

Quality assurance samples:

Set blank

Set spike, in percent recovery

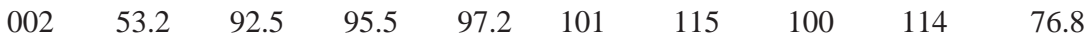

Set blank

Set spike, in percent recovery

$116<1.0<1.0 \quad<1.0 \quad<1.0 \quad<1.0 \quad<.1 \quad<.1 \quad<.1<1.0$

$\begin{array}{llllllllll}116 & 45.8 & 42.4 & 49.3 & 56.1 & 58.9 & 73.4 & 98.4 & 79.5 & 50.5\end{array}$

\begin{tabular}{lccccccccccc}
\hline $\begin{array}{c}\text { Site identifier } \\
\text { (fig. 2) }\end{array}$ & $\begin{array}{c}\text { Sample } \\
\text { date }\end{array}$ & $\begin{array}{c}\text { PCB } \\
\text { 151 }\end{array}$ & $\begin{array}{c}\text { PCB } \\
\mathbf{1 7 0}\end{array}$ & $\begin{array}{c}\text { PCB } \\
\mathbf{1 7 4}\end{array}$ & $\begin{array}{c}\text { PCB } \\
\mathbf{1 7 7}\end{array}$ & $\begin{array}{c}\text { PCB } \\
\mathbf{1 8 0}\end{array}$ & $\begin{array}{c}\text { PCB } \\
\mathbf{1 8 3}\end{array}$ & $\begin{array}{c}\text { PCB } \\
\mathbf{1 8 7}\end{array}$ & $\begin{array}{c}\text { PCB } \\
\mathbf{1 9 4}\end{array}$ & $\begin{array}{c}\text { PCB } \\
\mathbf{2 0 6}\end{array}$ & $\begin{array}{c}\sum \text { PCB } \\
\text { c }\end{array}$ \\
\hline OF4 & $3 / 2 / 2008$ & 0.50 & 2.3 & 1.7 & 0.85 & 4.4 & 0.88 & 1.5 & 1.9 & 1.2 & $\mathrm{E} 28$ \\
OF4 & $11 / 10 / 2008$ & .69 & 3.3 & 2.1 & 1.5 & 5.3 & 1.1 & 1.8 & 1.5 & .94 & $\mathrm{E} 23$ \\
OF4 duplicate & $11 / 10 / 2008$ & .37 & 2.5 & 1.4 & 1.1 & 3.9 & .79 & 1.4 & 1.2 & 1.4 & $\mathrm{E} 18$ \\
& & & & & & & & & & \\
OF5A & $3 / 2 / 2008$ & .44 & 2.1 & 2.3 & 1.3 & 3.9 & .90 & 2.0 & 2.5 & 1.2 & $\mathrm{E} 21$ \\
OF5A & $11 / 10 / 2008$ & .31 & 2.2 & 1.5 & .92 & 3.6 & .69 & 1.5 & 1.3 & .84 & $\mathrm{E} 19$
\end{tabular}

Sediment-quality guidelines:

Threshold effect concentration (TEC) ${ }^{1}$

Minimum reporting level (MRL)

Quality assurance samples:

Set blank

Set spike, in percent recovery

$\begin{array}{llllllllll}<.1 & <.1 & <.1 & <.1 & <.1 & <.1 & <.1 & <.1 & <.1 & -\end{array}$

Set blank

$\begin{array}{lllllllll}108 & 94.2 & 96.9 & 94.3 & 96.8 & 98.2 & 109 & 101 & 100\end{array}$

Set spike, in percent recovery

$\begin{array}{llllllllll}<.1 & <.1 & <.1 & <.1 & <.1 & <.1 & <.1 & <.1 & <.1 & -\end{array}$

${ }^{1}$ MacDonald and others (2000). 
Meandering Road Creek and Woods Inlet on the basis of suspended, streambed, and lake-bottom sediment samples collected in 2004 and 2006-07. Braun and others (2008) documented the extent of PCB contamination in Meandering Road Creek and Woods Inlet and identified runoff from outfalls 4 and 5 at AFP4 as prominent sources of PCBs in Meandering Road Creek and Woods Inlet. Concentrations of selected PCB congeners analyzed during 2003-07 for the previous USGS studies are listed in appendix 1.

\section{Engineering Controls Used to Alleviate Polychlorinated Biphenyl Contamination at Air Force Plant 4}

Lockheed Martin Corporation selected two companies to implement engineering controls to potentially alleviate PCB contamination in the drainage areas of outfalls 4 and 5 at AFP4. During late 2007 and early 2008 (about November 2007-February 2008), the companies used two types of engineering controls to clean up and contain PCBs in outfalls 4 and 5 storm-drainage areas (fig. 2).

The first engineering control was done by Freese and Nichols, Inc., and involved a one-time sweeping of pavement within the drainage areas of outfalls 4 and 5 (fig. 2) to reduce potential PCB migration. Pavement sweeping occurred before 6 a.m. or after 6 p.m., when it was likely few cars or employees would be present. Large, open paved areas were swept using standard, large-capacity pavement-sweeping equipment, whereas smaller paved areas were swept with compact sweeping equipment. Railroad tracks located within the drainage to outfall 4 were swept thoroughly to remove all debris around the rails and in depressions adjacent to rails. The area east of the electrical substation (fig. 2) within the concrete barriers in the outfall 4 drainage area also was swept. All debris was collected and stored in an on-site storage facility. The large-capacity pavement sweepers consist of a high-velocity air blower and vacuum with rotating circular brush heads; this type of equipment ensures that virtually all debris is collected in the hopper and little or no dust is generated. Smaller sweeper/vacuum vehicles of a similar type were used in areas too confined for the large-capacity sweepers. No water spray or mist-producing equipment was used in the sweeping process (Scott Harrison, Lockheed-Martin Corporation, written commun., 2009).

The second engineering control was done by Burns and McDonnell Engineering Company, Inc. About 560 square meters of the main electrical substation of AFP4 were regraded and covered with an asphaltic concrete cap (asphalt) (fig. 2). The top 8 centimeters (approximately) of gravel were removed from selected areas of the electrical substation; the soil subgrade was not excavated. Once the overlying gravel was stripped and stockpiled, any remaining gravel was compacted; then the previously stripped gravel was used as fill and compacted to bring the areas to 8 centimeters below the final grade. Dust control measures were used to minimize dust production. Because the excavated gravel was potentially contaminated with PCBs, the remaining stockpile of gravel was safely disposed of at an off-site location. Areas within the electrical substation, where potentially contaminated gravel was removed and the remaining gravel was compacted, were sprayed with a primer coat of liquid asphalt prior to installing the asphalt cap (fig. 2). The minimum design thickness of the asphalt cap was 8 centimeters, but in some instances the thickness was increased to match the grade of the concrete curb bordering the cap. The cap was sloped to induce drainage toward the outside perimeter (Scott Harrison, Lockheed-Martin Corporation, written commun., 2009).

\section{Approach}

\section{Collection and Processing of Suspended- Sediment Samples}

Two suspended-sediment samples each were collected at outfall 4 (OF4, fig. 2) and outfall 5 (OF5A, fig. 2) in 2008 for a total of four environmental samples. Suspended-sediment samples were collected by filling one 25-liter Nalgene carboy with runoff from the "first flush" (initial increase in flow) at each of the sample collection sites during a storm. Additional carboys were filled during some storms when the suspended-sediment concentration was too small (on the basis of visual inspection and professional judgment) to provide a sufficient sediment mass for chemical analyses. The 25-liter carboys were transported to the USGS Texas Water Science Center, North Texas Program Office in Fort Worth and stored on ice until filtering. Filtering each sample took several hours, so processing all samples from a storm typically took 1 to 2 days.

Suspended sediment was isolated from the stormwater samples by in-line filtration following the methods of Mahler and Van Metre (2003). Braun and others (2008) provides a detailed description of how the suspended-sediment samples were collected. One of the samples collected previously (October 10, 2006) at outfall 5 was collected at site OF5B (fig. 2). The small distance between sampling sites OF5A and OF5B should not affect the comparison because there is no additional source of runoff between the two sites.

\section{Analytical Methods}

The USGS NWQL analyzed the suspended-sediment samples for 60 halogenated compounds including PCBs, antibacterial and antifungal compounds, organochlorine pesticides, organofluorine pesticides, and polybrominated diphenyl ethers (PBDEs) and other flame retardants using a custom analytical method. Custom methods have not been completely 
evaluated with the USGS guidelines for developing official methods. Since the publication of Braun and others (2008), the NWQL revised the analytical method for measuring halogenated compounds, including PCBs, in sediments, which resulted in the following PCB congeners not being quantified for this report: $8,18,22,26,28,31,33,44$, and 95. The 18 PCB congeners analyzed in the samples collected during 2008 are listed in table 1. Although only PCB congeners are discussed in this report, concentrations of all other compounds that were analyzed in the suspended-sediment samples from outfalls 4 and 5 are listed in appendix 2 . The samples were extracted using an accelerated solvent extraction (ASE) system (Dionex Corporation, 2009) at a pressure of 13,800 kilopascals with a 50:50 (volume per volume) mixture of water and isopropyl alcohol at 120 degrees Celsius $\left({ }^{\circ} \mathrm{C}\right)$ for 40 minutes and a 20:80 mixture of water and isopropyl alcohol at $200{ }^{\circ} \mathrm{C}$ for an additional 40 minutes. The compounds of interest were isolated from the ASE extract using disposable solid-phase extraction (SPE) cartridges containing chemically modified $\mathrm{N}$-vinylpyrrolidone divinylbenzene resin in addition to amino-propyl-based resin. The SPE cartridge was dried with nitrogen gas and the extracted compounds eluted with a 4:1 mixture of dichloromethane and diethyl ether. The extract was concentrated under a stream of nitrogen gas, cleaned on 2 grams of Florosil eluted with a 94:6 mixture of pentane and acetone, concentrated again under a stream of nitrogen gas, and then exchanged into hexane. The extracts were analyzed on an Agilent Technologies Model 5975 capillary-column gas chromatograph/mass spectrometer (GC/ MS) using a 35-percent phenyl methylpolysiloxane capillarycolumn (Agilent Technologies, 2009) with the MS operated in the electron capture negative ion (ECNI) mode using ammonia as the reactant gas. The halogenated compounds were identified by selected ion monitoring (SIM) using the ions of interest (Mark Burkhardt and Steven Zaugg, U.S. Geological Survey, National Water Quality Laboratory, written commun., 2008). The analytical results and minimum reporting levels (MRLs) are listed in table 1. Compound concentrations were reported as estimated (E) when they were quantitatively identified below the MRL, because of matrix interference, or because the compounds are highly variable and there is questionable precision or accuracy with the analytical method.

\section{Quality Control}

For the four environmental samples collected during this study, the quality control for PCB analyses consisted of one duplicate sample, one laboratory blank sample, and spike and surrogate compound recovery rates for two sets of environmental samples. The recovery of surrogate compounds is monitored by the laboratory with every set of 12 environmental samples (Mark Burkhardt and Steven Zaugg, U.S. Geological Survey, National Water Quality Laboratory, written commun., 2008). The samples collected for this study were analyzed as part of different sets of environmental sam- ples, sets 002 and 116. All PCB congener concentrations in the blank sample were quantified at values less than the applicable PCB congener MRL of either 0.1 or 1.0 microgram per kilogram $(\mu \mathrm{g} / \mathrm{kg})($ table 1$)$. The average spike recoveries were 97 and 78 percent for sets 002 and 116, respectively. One sample from this study (OF4, November 10, 2008) was selected for duplicate analysis in set 116; however the duplicate for set 002 was not a sample from this study and is not included in this report. In the OF4 duplicate sample, the average relative percent difference (RPD) for compounds with concentrations greater than the respective MRLs was 33 percent. RPD was computed using the equation

$$
\mathrm{RPD}=\left|\mathrm{C}_{1}-\mathrm{C}_{2}\right| /\left(\left(\mathrm{C}_{1}+\mathrm{C}_{2}\right) / 2\right) \times 100,
$$

$$
\begin{aligned}
& \text { where } \\
& \mathrm{C}_{1}=\text { concentration from environmental sample; and } \\
& \mathrm{C}_{2}=\text { concentration from duplicate sample. }
\end{aligned}
$$

Surrogates were added as prior to extraction to monitor the extraction process. The average surrogate recoveries for set 002 were 71, 47, and 47 percent for 4,4-dibromooctafluorobiphenyl $\left(\mathrm{C}_{12} \mathrm{Br}_{2} \mathrm{~F}_{8}\right), 2,2^{\prime}, 3,3^{\prime}, 5,5^{\prime}, 6,6^{\prime}$-octachlorobiphenyl (PCB $202-{ }^{13} C_{12}$ ), and 1,1'-Bis( $p$-chlorophenyl)-2,2,2-trichloroethane (DDT- $d_{8}$ ), respectively. The average surrogate recoveries for set 116 were 40,59 , and 76 percent for $\mathrm{C}_{12} \mathrm{Br}_{2} \mathrm{~F}_{8}$, PCB $202-{ }_{-13}^{13} C_{12}$, and DDT- $d_{8}$, respectively. All surrogate recoveries are listed in appendix 2. Because a new, custom analytical method was used, acceptable ranges for spike and surrogate recoveries had not been established, and no past results using the same analytical method were available for comparison.

\section{Polychlorinated Biphenyls in Suspended-Sediment Samples from Outfalls to Meandering Road Creek}

Because of the small number of samples collected, it was not possible to statistically test if concentrations of PCB congeners obtained in this study were statistically different from concentrations of PCB congeners obtained during previous USGS studies. Eight suspended-sediment samples were collected at outfall 4 and three suspendedsediment samples (and one duplicate) at outfall 5 in previous studies, before the implementation of engineering controls (sweeping and capping) at AFP4. For comparison, results for the same 18 PCB congeners that were analyzed in suspendedsediment samples collected from outfalls 4 and 5 in the previous studies are listed in appendix 1. For this study, two suspended-sediment samples were collected at each of the outfalls in 2008, after the engineering controls had been implemented.

At outfall 4, $\Sigma \mathrm{PCB}$ before implementation of engineering controls ranged from E18 to E310 $\mu \mathrm{g} / \mathrm{kg}$ (appendix 1) and 
after implementation $\sum \mathrm{PCB}_{c}$ was E23 and E28 $\mu \mathrm{g} / \mathrm{kg}$ (table 1). At outfall $5, \Sigma \mathrm{PCB}_{c}$ before implementation of engineering controls ranged from E29 to E330 $\mu \mathrm{g} / \mathrm{kg}$ (appendix 1) and after implementation $\sum \mathrm{PCB}_{\mathrm{c}}$ was E19 and E21 $\mu \mathrm{g} / \mathrm{kg}$ (table 1).

Analyses of the results are limited to comparison to TEC sediment-quality guidelines (benchmark values) and graphical analysis of normalized concentrations of the selected congeners because of the small dataset. To compare $\mathrm{PCB}$ congener concentrations to the TEC, ratios of $\Sigma \mathrm{PCB}_{c}$ to the TEC were computed (fig. 3). For each sample, $\sum \mathrm{PCB}_{\mathrm{c}}$ was compared to the TEC of $59.8 \mu \mathrm{g} / \mathrm{kg}$ for total PCBs established by MacDonald and others (2000); in samples with ratios greater than $1, \sum \mathrm{PCB}_{\mathrm{c}}$ exceeds the TEC. $\sum \mathrm{PCB}_{\mathrm{c}}$ exceeded the TEC for 75 percent of the samples collected at outfall 4 and 67 percent of the samples collected at outfall 5 before the implementation of engineering controls. $\Sigma \mathrm{PCB}_{\mathrm{c}}$ did not exceed the TEC in samples collected at either outfall 4 or outfall 5 after the implementation of engineering controls.

Of the 18 PCB congeners that were quantified, 10 congeners were selected for graphical analysis on the basis of their detection frequency and range of chlorination. To normalize PCB concentrations, ratios of individual concentrations of PCB congeners to the sum of the 10 selected PCB congeners were determined, hereinafter referred to as congener ratios. The relative prominence of the 10 selected PCB congeners was evaluated by graphical analysis of congener ratios (fig. 4).

Before the implementation of engineering controls, congeners 110,138 , and 180 were most prominent at outfall 4 (fig. 4); this conclusion, as well as subsequent conclusions in this paragraph, are based solely on visual observations of figure 4. After the implementation of engineering controls,

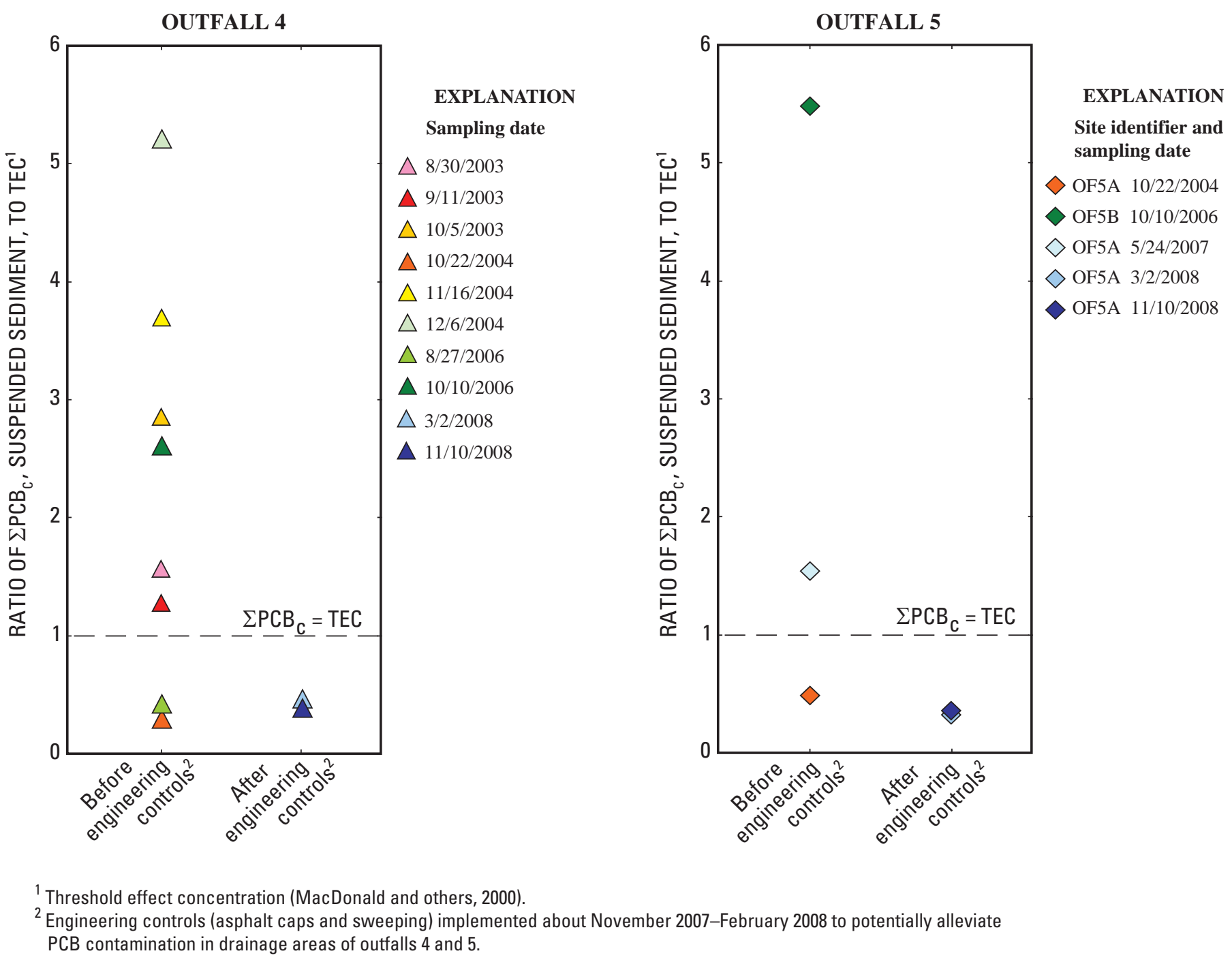

Figure 3. Ratios of total polychlorinated biphenyl (PCB) concentrations (sum of 18 reported congeners [ $\left.\Sigma P C B_{c}\right]$ ) to threshold effect concentration, a consensus-based sediment-quality guideline for PCBs, for suspended-sediment samples collected from outfalls 4 and 5, Air Force Plant 4, Fort Worth, Texas, 2003-08. 


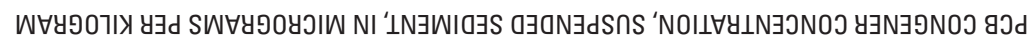
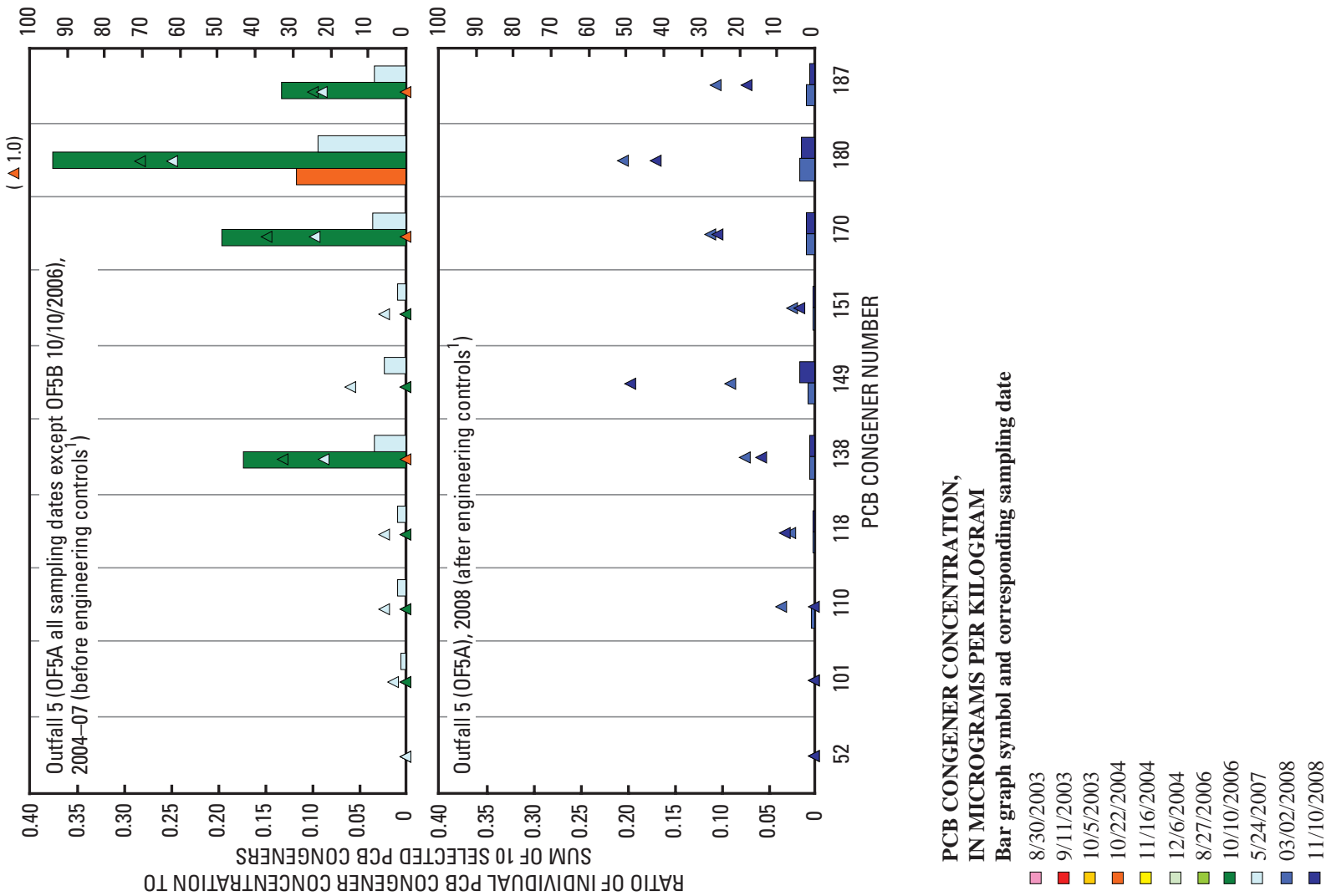

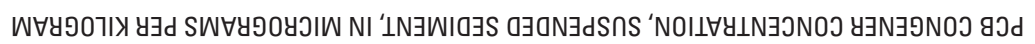
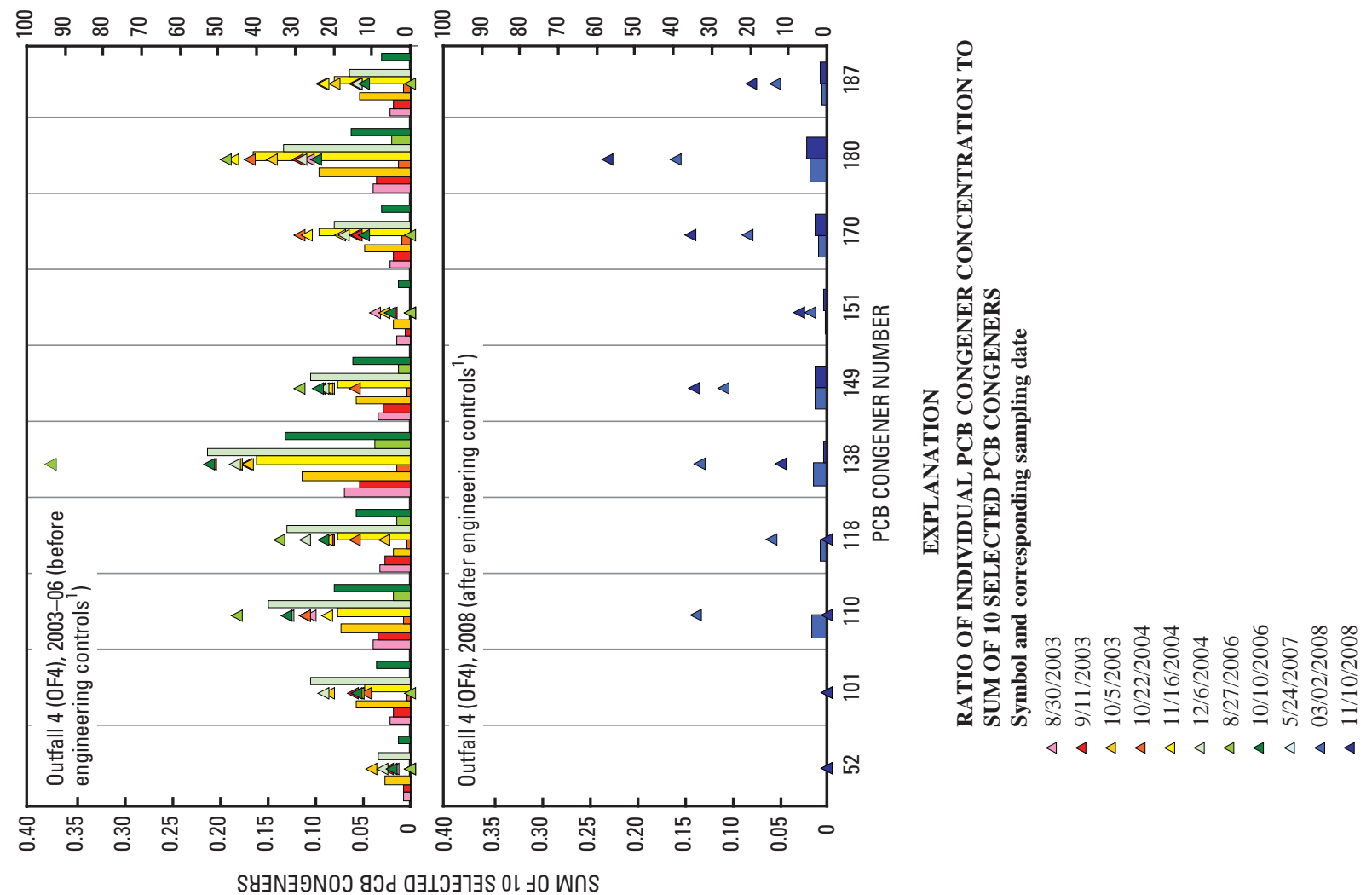

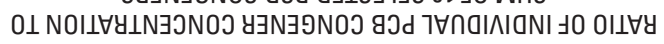


an overall decrease in concentrations of PCB congeners was observed in addition to a decrease in the prominence of the congener 110 and 138 ratios. A slight increase in the prominence of the congener 149 ratio was also observed after the implementation of engineering controls. This shift in prominence from lighter, less chlorinated congeners (110 and 138) to a heavier, more chlorinated congener (149) might have resulted from the engineering controls implemented at AFP4 near the sample collection sites. Additionally, the heavier, more chlorinated congeners are more likely to sorb to solids, while less chlorinated congeners are more likely to volatilize (Eisenreich, Capel, and Looney, 1983; Eisenreich and others, 1992; Pearson and others, 1996). The agitation associated with sweeping activities and gravel stripping might have induced volatilization that would have favored removal of the lighter congeners. The shift in congener ratios might also have resulted from the transition in analytical methods, or it could be the result of the small number of samples available for comparison.

Before the implementation of engineering controls, the suspended-sediment PCB concentrations at outfall 5 (fig. 4) exhibited a congener ratio pattern dominated by congener 138 and the more highly chlorinated PCB congeners (170, 180, and 187). PCB congeners 110 and 118, which were more prevalent at outfall 4, were either not detected at outfall 5 or detected at much lower concentrations. After the implementation of engineering controls, a decrease in concentrations of PCB congeners was observed in addition to a decrease in prominence of congeners 138 and 180. An increase in the prominence of congener 149 also occurred. The same possible explanations given for the shift in congener ratios at outfall 4 apply to the shift in congener ratios at outfall 5 .

\section{Summary}

Meandering Road Creek is an intermittent stream and tributary to Lake Worth, a reservoir on the West Fork Trinity River on the western edge of Fort Worth, Texas. U.S. Air Force Plant 4 (AFP4) is on the eastern shore of Woods Inlet, an arm of Lake Worth that extends south from the main body of the lake. Meandering Road Creek receives runoff from several stormwater outfalls that drain AFP4 to its terminus at Woods Inlet. Lake Worth and Meandering Road Creek have been the subject of several studies to characterize concentrations of polychlorinated biphenyls (PCBs) (and other contaminants) in the water and sediments of these water bodies; the sources of the PCBs are believed to originate primarily from AFP4. Two previous U.S. Geological Survey (USGS) reports documented elevated $\mathrm{PCB}$ concentrations in surficial sediment samples collected in Woods Inlet relative to those in surficial sediment samples collected in other parts of Lake Worth; the first report using samples collected during 20002001, the second using samples collected in 2003. The second report also identified some of the sources of PCBs to Lake
Worth. A third USGS report documented the extent of PCB contamination in Meandering Road Creek and Woods Inlet on the basis of samples collected during 2004 and 2006-07 and identified runoff from outfalls 4 and 5 at AFP4 as prominent sources of PCBs to Meandering Road Creek and Woods Inlet.

This report describes the results of a fourth study by the USGS, in cooperation with the Lockheed Martin Corporation, to investigate the concentration of PCBs in suspendedsediment samples in storm runoff from outfalls 4 and 5 at AFP4 following the implementation of engineering controls designed to potentially alleviate PCB contamination in the drainage areas of these outfalls. The first engineering control consisted of a one-time sweeping of pavement within the drainage areas of outfalls 4 and 5. The second engineering control involved regrading and installing an asphalt cap over about 560 square meters of the main electrical substation of AFP4. The USGS collected suspended-sediment samples from outfalls 4 and 5 during storms on March 2 and November 10, 2008, and analyzed the samples for selected PCBs. The sums of concentrations of 18 reported PCB congeners ( $\left.\sum \mathrm{PCB}_{\mathrm{c}}\right)$ in suspended-sediment samples collected during 2003-07 (before implementation of engineering controls) for the previous USGS studies are compared to $\Sigma \mathrm{PCB}_{\mathrm{c}}$ in suspended-sediment samples collected during 2008 (after implementation of engineering controls). Comparability of PCB concentrations before and after implementation of engineering controls is limited because of the small number of samples collected and lack of runoff and precipitation data.

$\sum \mathrm{PCB}_{\mathrm{c}}$ in suspended-sediment samples before implementation of engineering controls ranged from estimated (E)18 to E310 micrograms per kilogram $(\mu \mathrm{g} / \mathrm{kg})$ and E29 to E330 $\mu \mathrm{g} / \mathrm{kg}$ for outfalls 4 and 5, respectively. $\Sigma \mathrm{PCB}$ after implementation was E23 and E28 $\mu \mathrm{g} / \mathrm{kg}$ and E19 and E21 $\mu \mathrm{g} / \mathrm{kg}$ for outfalls 4 and 5 , respectively.

The $\Sigma \mathrm{PCB}_{\mathrm{c}}$ in suspended-sediment samples collected at AFP4 before and after implementation of engineering controls also is compared to the sediment-quality guideline threshold effect concentration (TEC), the concentration below which adverse effects to benthic biota rarely occur. $\Sigma \mathrm{PCB}_{\mathrm{c}}$ exceeded the TEC for 75 percent of the samples collected at outfall 4 and 67 percent of the samples collected at outfall 5 before the implementation of engineering controls. $\Sigma \mathrm{PCB}_{\mathrm{c}}$ did not exceed the TEC in samples collected at either outfall 4 or outfall 5 after the implementation of engineering controls.

The relative prominence of 10 selected PCB congeners was evaluated by graphical analysis of ratios of individual concentrations of the $10 \mathrm{PCB}$ congeners to the sum of these PCB congeners. Before the implementation of engineering controls, PCB congeners 110, 138, and 180 were most prominent in the suspended-sediment samples at outfall 4. After the implementation of engineering controls, an overall decrease in concentrations of PCB congeners was observed in addition to a decrease in the prominence of congeners 110 and 138 and an increase in the prominence of congener 149. This shift in prominence from lighter, less chlorinated congeners (110 and 138) to a heavier, more chlorinated congener (149) might 
have resulted from the engineering controls implemented at AFP4. Before the implementation of engineering controls, the suspended-sediment PCB concentrations at outfall 5 exhibited a congener ratio pattern dominated by congener 138 and the more highly chlorinated PCB congeners (170, 180, and 187). After the implementation of engineering controls, a decrease in concentrations of PCB congeners was observed in addition to a decrease in the prominence of congeners 138 and 180 and an increase in the prominence of congener 149. The shift in congener ratios at outfalls 4 and 5 also might have resulted from the engineering controls implemented at AFP4.

\section{References Cited}

Agency for Toxic Substances and Disease Registry, 2001, ToxFAQ for polychlorinated biphenyls (PCBs): accessed July 26, 2007, at http://www.atsdr.cdc.gov/tfacts17.pdf.

Agilent Technologies, 2009, DB-35 GC columns: accessed January 29, 2010, at http://www.chem.agilent.com/en-US/ Products/consumables/columns/gcandgc-ms/jwdb-35/pages/ default.aspx.

Besse, R.E., Van Metre, P.C., and Wilson, J.T., 2005, Distribution and sources of polychlorinated biphenyls in Woods Inlet, Lake Worth, Fort Worth, Texas, 2003: U.S. Geological Survey Scientific Investigations Report 2005-5064, $40 \mathrm{p}$.

Braun, C.L., Wilson, J.T., and Van Metre, P.C., 2008, Degree of contamination and sources of polychlorinated biphenyls in Meandering Road Creek and Woods Inlet of Lake Worth, Fort Worth, Texas, 2004 and 2006-07: U.S. Geological Survey Scientific Investigations Report 2008-5177, $64 \mathrm{p}$.

CH2M Hill, 1984, Installation restoration program records search for Air Force Plant 4: Prepared for U.S. Air Force [variously paged].

Dionex Corporation, 2009, Accelerated solvent extraction system: accessed September 8, 2009, at http://www.dionex. com/en-us/instrument-ase/ins7387.html.

Earth Tech, Inc., 2005, West side DNAPL and PCB investigation at Air Force Plant 4, Fort Worth, Texas: Prepared for U.S. Air Force, Aeronautical Systems Center, Environmental Management Directorate, Wright-Patterson Air Force Base, Ohio, Contract No. F41624-00-D-8023 [variously paged].

Eisenreich, S.J., Baker, J.E., Franz, T., Swanson, M., Rapaport, R.A., Strachan, W.M.J., and Hites, R.A., 1992, Atmospheric deposition of hydrophobic organic contaminants to the Laurentian Great Lakes, in Schnoor, J.L., ed., Fate of pesticides and chemicals in the environment: New York, John Wiley \& Sons, p. 51-78.
Eisenreich, S.J., Capel, P.D., and Looney, B.B., 1983, PCB dynamics in Lake Superior water, in Mackay, D., Paterson, S., Eisenreich, S.J., and Simmons, M.S., eds., Physical behavior of PCBs in the Great Lakes: Ann Arbor, Mich., Ann Arbor Science, p. 181-211.

Erickson, M.D., 2001, Introduction-PCB properties, uses, occurrence, and regulatory history, in Robertson, L.W., and Hansen, L.G., eds., PCBs-Recent advances in environmental toxicology and health effects: Lexington, Ky., University Press of Kentucky, p. xi-xxvii.

Harwell, G.R., Van Metre, P.C., Wilson, J.T., and Mahler, B.J., 2003, Spatial distribution and trends in trace elements, polycyclic aromatic hydrocarbons, organochlorine pesticides, and polychlorinated biphenyls in Lake Worth sediment, Fort Worth, Texas: U.S. Geological Survey WaterResources Investigations Report 03-4269, 56 p.

International Technology Corporation, 2001, West side site investigation report, Air Force Plant 4, Fort Worth, Texas: Monroeville, Penn., International Technology Corporation, $110 \mathrm{p}$.

Long, E.R., MacDonald, D.D., Smith, S.L., and Calder, F.D., 1995, Incidence of adverse biological effects within ranges of chemical concentrations in marine and estuarine sediments: Environmental Management, v. 19, p. 81-97.

Long, G.R., Ayers, M.A., Callender, Edward, and Van Metre, P.C., 2003, Trends in chemical concentration in sediment cores from three lakes in New Jersey and one lake on Long Island, New York: U.S. Geological Survey Water-Resources Investigations Report 02-4272, 23 p.

MacDonald, D.D., Ingersoll, C.G., and Berger, T.A., 2000, Development and evaluation of consensus-based sediment quality guidelines for freshwater ecosystems: Archives of Environmental Contamination and Toxicology, v. 39, p. 20-31, accessed February 1, 2010, at http://www. springerlink.com/content/89h1txc7f5a07ybc/.

Mahler, B.J., and Van Metre, P.C., 2003, A simplified approach for monitoring hydrophobic organic contaminants associated with suspended sediments-Methodology and applications: Archives of Environmental Contamination and Toxicology, v. 44, no. 3, p. 288-297.

Moring, J.B., 2002, Data on occurrence of selected trace metals, organochlorines, and semivolatile organic compounds in edible fish tissues from Lake Worth, Fort Worth, Texas, 1999: U.S. Geological Survey Open-File Report 02-016, $23 \mathrm{p}$.

Pearson, R.F., Hornbuckle, K.C., Eisenreich, S.J., and Swackhamer, D.L., 1996, PCBs in Lake Michigan water revisited: Environmental Science and Technology, v. 30, no. 5 , p. $1,429-1,436$. 
RUST Geotech, 1995, Air Force Plant 4, remedial investigation and preliminary assessment/site inspection report, volume 1: Prepared for U.S. Air Force, Headquarters Aeronautical Systems Center, Wright-Patterson Air Force Base, Ohio, Department of Energy Contract No. DE-AC04861D12584, GJPO-WMP-75, 545 p.

Texas Department of Health, 1998, Public health assessment, U.S. Air Force Plant No. 4 (General Dynamics), Fort Worth, Tarrant County, Texas: Comprehensive Environmental Response, Compensation, and Liability Information System, CERCLIS no. TX7572024605, 39 p.

Texas Department of State Health Services, 2010, Fish consumption advisories and bans: accessed February 9, 2010, at http://www.dshs.state.tx.us/seafood/survey.shtm\#advisory.

U.S. Environmental Protection Agency, 1990, National priorities list (NPL)_NPL site narrative for Air Force
Plant \#4 (General Dynamics): accessed February 8, 2010, at http://www.epa.gov/superfund/sites/npl/nar786.htm.

U.S. Environmental Protection Agency, 2009, Air Force Plant 4, Fort Worth, Tarrant County, Texas, identification number TXD7572024605-Current status report, updated October 2009: accessed January 29, 2010, at http://www.epa.gov/ Region6/6sf/pdffiles/0603610.pdf.

Van Metre, P.C., Callender, Edward, and Fuller, C.C., 1997, Historical trends in organochlorine compounds in river basins identified using sediment cores from reservoirs: Environmental Science and Technology, v. 31, no. 8, p. 2,339-2,344.

Van Metre, P.C., Wilson, J.T., Callender, Edward, and Fuller, C.C., 1998, Similar rates of decrease of persistent, hydrophobic and particle-reactive contaminants in riverine systems: Environmental Science and Technology, v. 32, no. 21 , p. 3,312-3,317. 
Blank Page 
Appendixes 1-2 
Blank Page 
Appendix 1. Concentrations of selected polychlorinated biphenyl congeners in suspended-sediment samples collected from outfalls 4 and 5, Air Force Plant 4, Fort Worth, Texas, 2003-07.

[In micrograms per kilogram except as noted; PCB, polychlorinated biphenyl; OF4, outfall 4; E, estimated; <, nondetection less than minimum reporting level; OF5, outfall 5; dup, duplicate; - -, not available; $\Sigma \mathrm{PCB}_{c}$, sum of $18 \mathrm{PCB}$ congeners]

\begin{tabular}{|c|c|c|c|c|c|c|c|c|c|c|c|c|}
\hline $\begin{array}{c}\text { U.S. Geological } \\
\text { Survey station } \\
\text { number }\end{array}$ & $\begin{array}{c}\text { Site } \\
\text { identifier } \\
\text { (fig. 2) }\end{array}$ & $\begin{array}{c}\text { Sample } \\
\text { date }\end{array}$ & $\begin{array}{c}\text { PCB } \\
49\end{array}$ & $\begin{array}{c}\text { PCB } \\
52\end{array}$ & $\begin{array}{c}\text { PCB } \\
70\end{array}$ & $\begin{array}{c}\text { PCB } \\
101\end{array}$ & $\begin{array}{c}\text { PCB } \\
110\end{array}$ & $\begin{array}{c}\text { PCB } \\
118\end{array}$ & $\begin{array}{c}\text { PCB } \\
138\end{array}$ & $\begin{array}{c}\text { PCB } \\
146\end{array}$ & $\begin{array}{c}\text { PCB } \\
149\end{array}$ & $\begin{array}{c}\text { PCB } \\
151\end{array}$ \\
\hline 08045359 & OF4 & $08 / 30 / 2003$ & E0.75 & E1.6 & E2.6 & E5.1 & 9.7 & E8.0 & 17 & E2.4 & E8.4 & E3.5 \\
\hline 08045359 & OF4 & $09 / 11 / 2003$ & E.60 & E1.8 & E2.3 & $\mathrm{E} 4.5$ & E8.3 & E6.4 & E13 & E2.1 & E7.1 & E1.5 \\
\hline 08045359 & OF4 & $10 / 05 / 2003$ & $<11$ & E6.6 & $<11$ & 14 & 18 & $\mathrm{E} 4.4$ & 28 & E3.4 & 14 & $\mathrm{E} 4.4$ \\
\hline 08045359 & OF4 & $10 / 22 / 2004$ & $<1.0$ & $<1.0$ & $<1.0$ & E.8 & 1.9 & 1.0 & 3.6 & $<1.0$ & 1.0 & $<1.0$ \\
\hline 08045359 & OF4 & $12 / 06 / 2004$ & $<14$ & E8.2 & E10 & E26 & E37 & E32 & E53 & $<14$ & E26 & $<14$ \\
\hline 08045359 & OF4 & $08 / 27 / 2006$ & $<36$ & $<36$ & $<36$ & $<36$ & E4.5 & E3.4 & E9.4 & $<36$ & E2.9 & $<36$ \\
\hline 08045359 & OF4 & $10 / 10 / 2006$ & $<10$ & E3.0 & E6.8 & E8.7 & 20 & 14 & 33 & E3.9 & 15 & E3.3 \\
\hline 324638097270901 & OF5A & $10 / 22 / 2004$ & $<45$ & $<45$ & $<45$ & $<45$ & $<45$ & $<45$ & $<45$ & $<45$ & $<45$ & $<45$ \\
\hline
\end{tabular}

Sediment-quality guidelines:

Threshold effect concentration (TEC) ${ }^{2}$

\begin{tabular}{|c|c|c|c|c|c|c|c|c|c|c|c|c|c|}
\hline \multirow{2}{*}{$\begin{array}{c}\text { Site } \\
\text { identifier } \\
\text { (fig. 2) }\end{array}$} & \multirow{2}{*}{$\begin{array}{l}\text { Sample } \\
\text { date }\end{array}$} & \multirow{2}{*}{$\begin{array}{l}\text { PCB } \\
170\end{array}$} & \multirow{2}{*}{$\begin{array}{l}\text { PCB } \\
174\end{array}$} & \multirow{2}{*}{$\begin{array}{l}\text { PCB } \\
177\end{array}$} & \multirow{2}{*}{$\begin{array}{l}\text { PCB } \\
180\end{array}$} & \multirow{2}{*}{$\begin{array}{l}\text { PCB } \\
183\end{array}$} & \multirow{2}{*}{$\begin{array}{l}\text { PCB } \\
187\end{array}$} & \multirow{2}{*}{$\begin{array}{l}\text { PCB } \\
194\end{array}$} & \multirow{2}{*}{$\begin{array}{l}\text { PCB } \\
206\end{array}$} & \multirow{2}{*}{$\Sigma \mathbf{P C B}_{\mathrm{c}}$} & \multicolumn{3}{|c|}{$\begin{array}{l}\text { Surrogates, in percent recovery } \\
\text { (acceptable range) }\end{array}$} \\
\hline & & & & & & & & & & & Isodrin & $\begin{array}{l}\text { alpha- } \\
\text { HCH-d6 }\end{array}$ & $\begin{array}{l}\text { Nonachloro- } \\
\text { biphenyl }\end{array}$ \\
\hline OF4 & 08/30/2003 & E5.4 & $\mathrm{E} 4.5$ & E2.4 & 9.9 & E3.4 & E5.3 & E2.8 & $<0.16$ & E93 & -- & -- & -- \\
\hline OF4 & $09 / 11 / 2003$ & E4.2 & E3.2 & E2.0 & E8.8 & E2.2 & $\mathrm{E} 4.4$ & E2.1 & $<1.0$ & E75 & -- & -- & -- \\
\hline $\mathrm{OF} 4$ & $10 / 05 / 2003$ & 12 & E10 & E5.4 & 24 & E5.0 & 13 & E3.4 & $<11$ & E170 & - & - & -- \\
\hline OF4 & $11 / 16 / 2004$ & E24 & E13 & $<19$ & E41 & $<19$ & E20 & E14 & $<19$ & E220 & 57 (42-94) & $77(21-140)$ & $120(19-125)$ \\
\hline OF4 & $12 / 06 / 2004$ & E20 & E11 & E8.8 & E33 & $<14$ & E16 & E9.7 & $<14$ & E310 & $61(42-94)$ & $85(21-140)$ & $110(19-125)$ \\
\hline OF4 & 08/27/2006 & $<36$ & $<36$ & $<36$ & E4.8 & $<36$ & $<36$ & $<36$ & $<36$ & E25 & $72(41-121)$ & $83(58-124)$ & $76(14-142)$ \\
\hline OF4 & $10 / 10 / 2006$ & E7.5 & E5.3 & E3.5 & 15 & $<10$ & E7.6 & E3.7 & E2.9 & E160 & $76(41-121)$ & $75(58-124)$ & $81(14-142)$ \\
\hline OF5A & 05/24/2007 & 9.0 & 8.4 & 5.9 & 23 & 4.1 & 8.4 & 7.9 & 4.2 & E93 & $50(41-121)$ & $66(58-124)$ & $92(14-142)$ \\
\hline $\begin{array}{r}\text { OF5A } \\
\text { dup }\end{array}$ & 05/24/2007 & 9.3 & 8.7 & 6.1 & 21 & 4.3 & 8.7 & 7.9 & 4.2 & E94 & $50(41-121)$ & $62(58-124)$ & $90(14-142)$ \\
\hline
\end{tabular}

\section{Sediment-quality guidelines:}

Threshold effect concentration (TEC) $)^{2}$

\footnotetext{
${ }^{1}$ Sample required custom preparation (air dried) at laboratory because normal centrifugation could not separate solids from water.

${ }^{2}$ MacDonald and others (2000).
} 
Appendix 2. Concentrations of antibacterial, antifungal, pesticide, and flame retardant compounds in suspended-sediment samples collected from outfalls 4 and 5, Air Force Plant 4, Fort Worth, Texas, 2008.

[In micrograms per kilogram except as noted; OF4, outfall 4; <, nondetection less than minimum reporting level; E, estimated; dup, duplicate; OF5, outfall 5; - -, not available; $\Sigma$, sum; $\Sigma \mathrm{PCB}_{\mathrm{c}}$, sum of $18 \mathrm{PCB}$ congeners (table 1); $\mathrm{C}_{12} \mathrm{Br}_{2} \mathrm{~F}_{8}, 4$,4-dibromooctafluorobiphenyl; PCB 202-1 ${ }^{13} C_{12}$, 2,2'3,3'5,5'6,6'-octachlorobiphenyl; DDT- $d_{8}, 1,1$-Bis( $p$-chlorophenyl)-2,2,2-trichloroethane]

\begin{tabular}{|c|c|c|c|c|c|c|c|c|c|c|}
\hline \multirow{2}{*}{$\begin{array}{c}\text { U.S. Geological } \\
\text { Survey station } \\
\text { number }\end{array}$} & \multirow{2}{*}{$\begin{array}{c}\text { Site } \\
\text { identifier } \\
\text { (fig. 2) }\end{array}$} & \multirow[b]{2}{*}{ Sample date } & \multirow[b]{2}{*}{$\begin{array}{c}\text { Set } \\
\text { number }\end{array}$} & \multirow{2}{*}{$\begin{array}{l}\text { Octa- } \\
\text { chloro- } \\
\text { styrene }\end{array}$} & \multicolumn{2}{|c|}{$\begin{array}{l}\text { Antibacterial/ } \\
\text { antifungal }\end{array}$} & \multicolumn{4}{|c|}{ Pesticides } \\
\hline & & & & & $\begin{array}{l}\text { Methoxy- } \\
\text { triclosan }\end{array}$ & $\begin{array}{l}\text { Triclo- } \\
\text { san }\end{array}$ & $\begin{array}{c}\text { Ben- } \\
\text { fluralin } \\
\text { (benefin) }\end{array}$ & $\begin{array}{l}\text { Chlori- } \\
\text { dazon } \\
\text { (PCA) }\end{array}$ & $\begin{array}{l}\text { Chlor- } \\
\text { pyrifos }\end{array}$ & $\begin{array}{l}\text { cis- } \\
\text { Chlor- } \\
\text { dane }\end{array}$ \\
\hline 08045359 & OF4 & $3 / 2 / 2008$ & 002 & $<1.0$ & $<1.0$ & 17 & E0.15 & 0.16 & 3.5 & 1.1 \\
\hline 08045359 & OF4 & $11 / 10 / 2008$ & 116 & $<1.0$ & $<1.0$ & 9.2 & E.015 & $<.1$ & $<.1$ & 1.3 \\
\hline 324638097270901 & OF5A & $3 / 2 / 2008$ & 002 & $<1.0$ & $<1.0$ & $<5.0$ & $<.1$ & $<.1$ & 1.2 & .33 \\
\hline 324638097270901 & OF5A & $11 / 10 / 2008$ & 116 & $<1.0$ & $<1.0$ & 27 & $<.1$ & $<.1$ & $<.1$ & .46 \\
\hline \multicolumn{11}{|c|}{ Sediment quality guidelines: } \\
\hline \multicolumn{11}{|c|}{ Quality assurance samples: } \\
\hline \multicolumn{3}{|c|}{ Set blank } & 002 & $<1.0$ & $<1.0$ & E.43 & $<.1$ & E.085 & $<.1$ & $<.1$ \\
\hline \multicolumn{3}{|c|}{ Set spike, in percent recovery } & 002 & 86.6 & 152 & 94 & 36.9 & 158 & 86.3 & 87.5 \\
\hline \multicolumn{3}{|l|}{ Set blank } & 116 & $<1.0$ & $<1.0$ & 1.31 & $<.1$ & $<.1$ & $<.1$ & $<.1$ \\
\hline \multicolumn{3}{|c|}{ Set spike, in percent recovery } & 116 & 77.4 & 92.7 & 102 & 52.6 & 98.9 & 73.2 & 89.7 \\
\hline
\end{tabular}

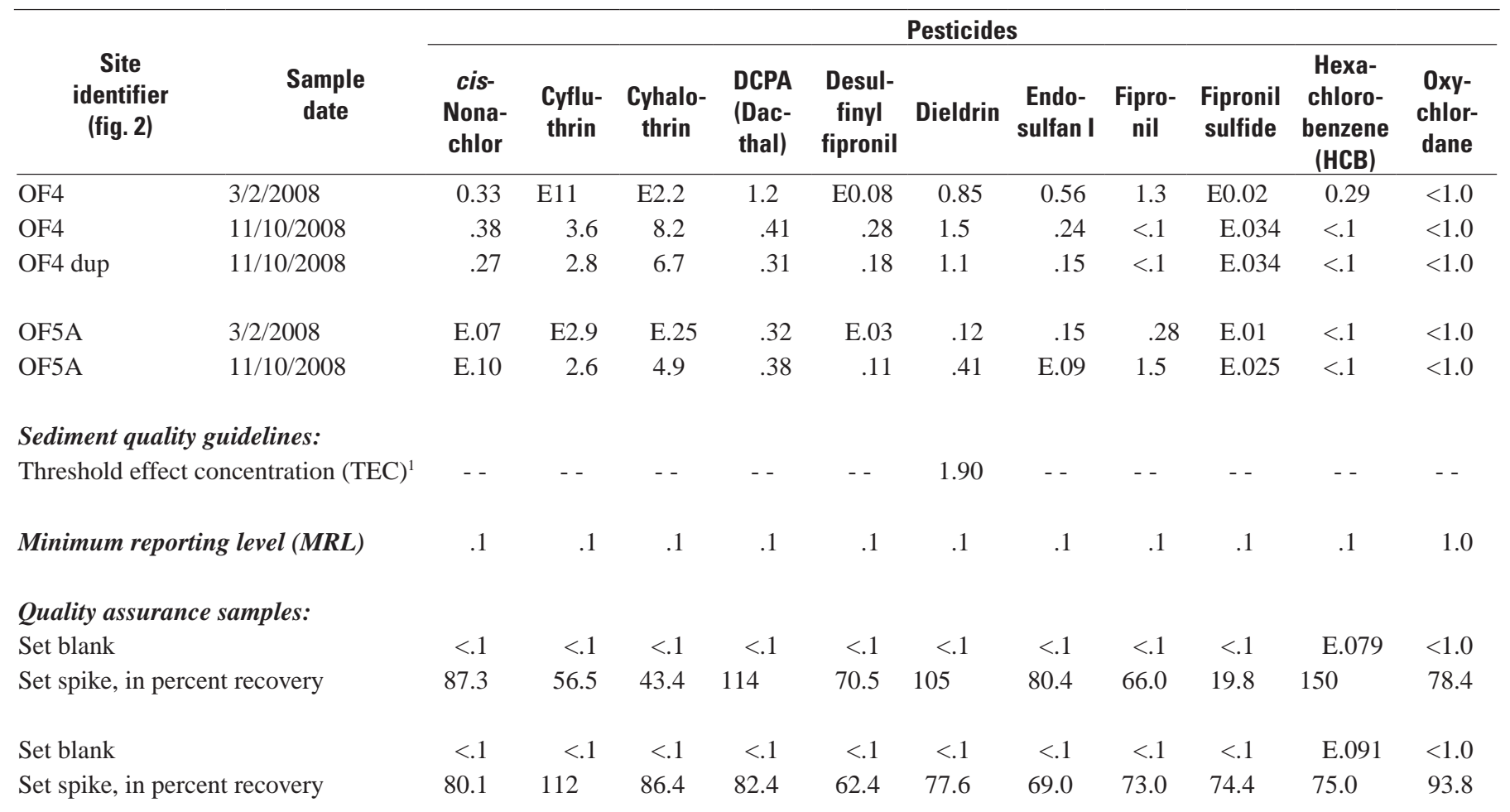


Appendix 2. Concentrations of antibacterial, antifungal, pesticide, and flame retardant compounds in suspended-sediment samples collected from outfalls 4 and 5, Air Force Plant 4, Fort Worth, Texas, 2008-Continued.

\begin{tabular}{|c|c|c|c|c|c|c|c|c|c|c|c|c|}
\hline \multirow[b]{2}{*}{$\begin{array}{c}\text { Site } \\
\text { identifier } \\
\text { (fig. 2) }\end{array}$} & \multirow[b]{2}{*}{$\begin{array}{l}\text { Sample } \\
\text { date }\end{array}$} & \multicolumn{11}{|c|}{ Pesticides } \\
\hline & & $\begin{array}{l}\text { Oxy- } \\
\text { fluor- } \\
\text { fen }\end{array}$ & $\begin{array}{l}\text { Pendi- } \\
\text { methlin }\end{array}$ & $\begin{array}{l}\text { Penta- } \\
\text { chloro- } \\
\text { nitro- } \\
\text { benzene }\end{array}$ & $\begin{array}{l}p, p^{\prime}- \\
\text { DDD }\end{array}$ & $\begin{array}{l}p, p^{\prime}- \\
\text { DDE }\end{array}$ & $\begin{array}{l}p, p^{\prime}- \\
\text { DDT }\end{array}$ & $\begin{array}{l}\text { Teflu- } \\
\text { thrin }\end{array}$ & $\begin{array}{l}\text { Tetra- } \\
\text { difon }\end{array}$ & $\begin{array}{l}\text { trans- } \\
\text { Chlor- } \\
\text { dane }\end{array}$ & $\begin{array}{l}\text { trans- } \\
\text { Nona- } \\
\text { chlor }\end{array}$ & $\begin{array}{c}\text { Tri- } \\
\text { fluralin }\end{array}$ \\
\hline OF4 & $3 / 2 / 2008$ & $<5.0$ & E1.0 & $<1.0$ & $<1.0$ & E0.88 & $<1.0$ & $<0.1$ & $<0.1$ & 0.88 & 0.68 & E0.25 \\
\hline OF4 & $11 / 10 / 2008$ & $<5.0$ & $<1.0$ & $<1.0$ & $<1.0$ & E. 81 & $<1.0$ & $<.1$ & $<.1$ & .95 & .61 & E.024 \\
\hline OF4 dup & $11 / 10 / 2008$ & $<5.0$ & $<1.0$ & $<1.0$ & $<1.0$ & E. 62 & $<1.0$ & $<.1$ & $<.1$ & .71 & .42 & E.016 \\
\hline OF5A & $3 / 2 / 2008$ & $<5.0$ & $<1.0$ & $<1.0$ & $<1.0$ & E.41 & $<1.0$ & $<.1$ & $<.1$ & .23 & .16 & $<.10$ \\
\hline OF5A & $11 / 10 / 2008$ & $<5.0$ & $<1.0$ & $<1.0$ & $<1.0$ & 3.7 & $<1.0$ & $<.1$ & $<.1$ & .38 & .21 & $<.10$ \\
\hline \multicolumn{13}{|c|}{ Sediment quality guidelines: } \\
\hline \multicolumn{2}{|c|}{$\begin{array}{l}\text { Threshold effect concentration } \\
\text { (TEC) })^{1}\end{array}$} & -- & -- & -- & 4.88 & 3.16 & 4.16 & -- & -- & -- & -- & -- \\
\hline \multicolumn{2}{|c|}{ Minimum reporting level (MRL) } & 5.0 & 1.0 & 1.0 & 1.0 & 1.0 & 1.0 & .1 & .1 & .1 & .1 & .1 \\
\hline \multicolumn{13}{|c|}{ Quality assurance samples: } \\
\hline \multicolumn{2}{|l|}{ Set blank } & $<5.0$ & $<1.0$ & $<1.0$ & $<1.0$ & $<1.0$ & $<1.0$ & $<.1$ & $<.1$ & $<.1$ & $<.1$ & $<.1$ \\
\hline \multicolumn{2}{|c|}{ Set spike, in percent recovery } & 116 & 67.0 & 114 & 97.6 & 134 & 110 & 51.8 & 54.5 & 82.7 & 76.7 & 38.3 \\
\hline \multicolumn{2}{|c|}{ Set blank } & $<5.0$ & $<1.0$ & $<1.0$ & $<1.0$ & $<1.0$ & $<1.0$ & $<.1$ & $<.1$ & $<.1$ & $<.1$ & $<.1$ \\
\hline \multicolumn{2}{|c|}{ Set spike, in percent recovery } & 79.5 & 74.3 & 93.3 & 74.6 & 103 & 100 & 77.2 & 80.6 & 82.9 & 83.6 & 49.9 \\
\hline
\end{tabular}

\begin{tabular}{|c|c|c|c|c|c|c|c|c|}
\hline \multirow{2}{*}{$\begin{array}{c}\text { Site } \\
\text { identifier } \\
\text { (fig. 2) }\end{array}$} & \multirow{2}{*}{$\begin{array}{l}\text { Sample } \\
\text { date }\end{array}$} & \multicolumn{7}{|c|}{ Polybrominated diphenyl ethers (PBDEs) and other flame retardants } \\
\hline & & $\begin{array}{c}\text { PBDE } \\
47\end{array}$ & $\begin{array}{c}\text { PBDE } \\
66\end{array}$ & $\begin{array}{c}\text { PBDE } \\
71\end{array}$ & $\begin{array}{c}\text { PBDE } \\
85\end{array}$ & $\begin{array}{c}\text { PBDE } \\
99\end{array}$ & $\begin{array}{c}\text { PBDE } \\
100\end{array}$ & $\begin{array}{c}\text { PBDE } \\
138\end{array}$ \\
\hline OF4 & $3 / 2 / 2008$ & 13 & 0.59 & $<0.1$ & 0.92 & 14 & 4.5 & 0.49 \\
\hline OF4 & $11 / 10 / 2008$ & 6.4 & .31 & $<.1$ & .62 & 9.5 & 2.4 & .66 \\
\hline OF4 dup & $11 / 10 / 2008$ & 3.8 & .23 & $<.1$ & .41 & 4.7 & 1.3 & .87 \\
\hline OF5A & 3/2/2008 & 3.5 & .20 & $<.1$ & .28 & 4.3 & 1.3 & .37 \\
\hline OF5A & $11 / 10 / 2008$ & 2.5 & $<.1$ & $<.1$ & .34 & 3.6 & .95 & .35 \\
\hline
\end{tabular}

Sediment quality guidelines:

Threshold effect concentration $(\mathrm{TEC})^{1}$

Minimum reporting level (MRL)

Quality assurance samples:

Set blank

Set spike, in percent recovery

Set blank

Set spike, in percent recovery

$\begin{array}{cccc}.344 & <.1 & <.1 & <.1 \\ 256 & 60.0 & 106 & 117\end{array}$

$<.1$

83.0
46.7
$<.1$

84.4

$\begin{array}{ccc}\text { E.098 } & <.1 & <.1 \\ 130 & 109 & 112\end{array}$

112 
Appendix 2. Concentrations of antibacterial, antifungal, pesticide, and flame retardant compounds in suspended-sediment samples collected from outfalls 4 and 5, Air Force Plant 4, Fort Worth, Texas, 2008_-Continued.

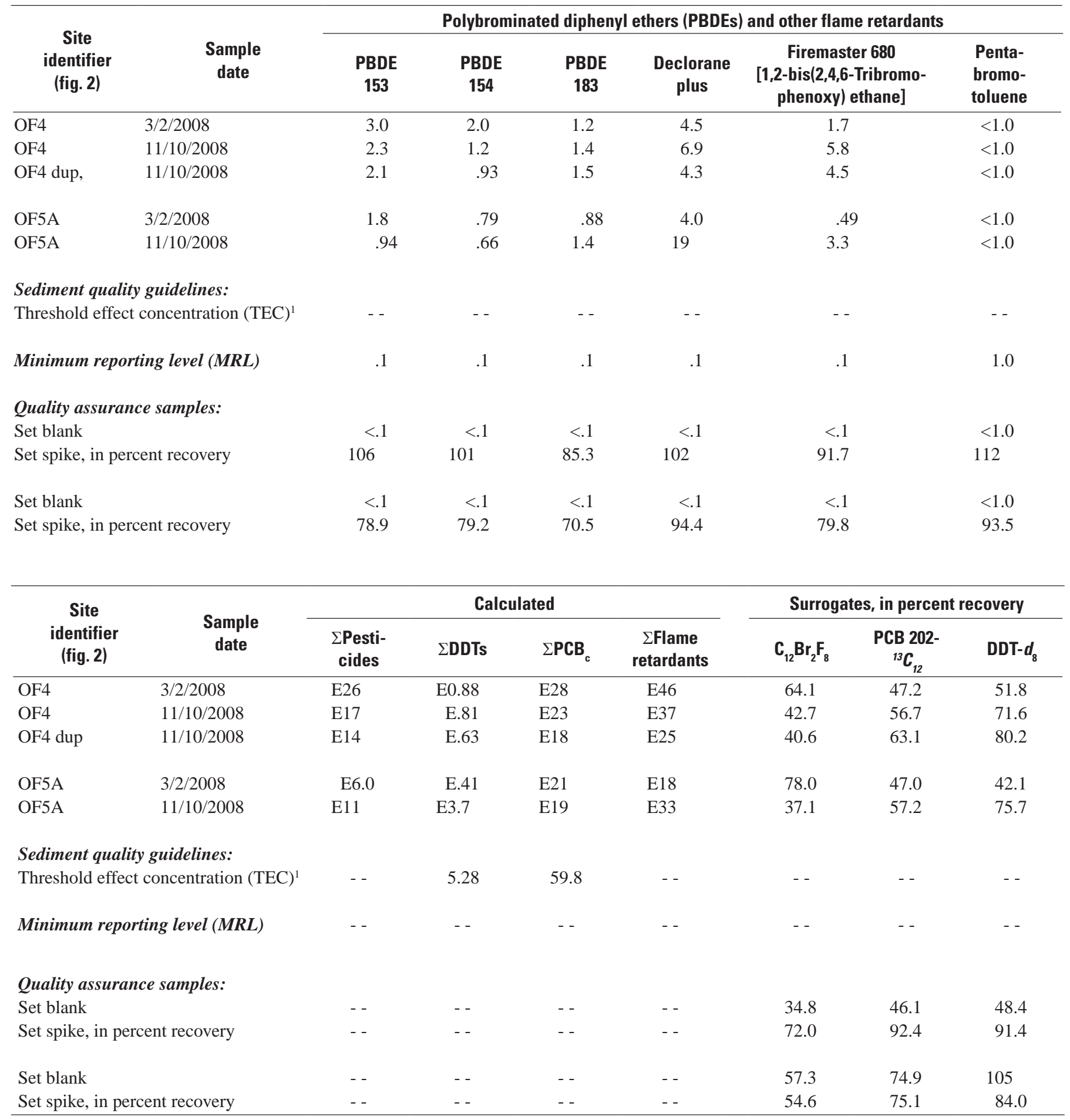

${ }^{1}$ MacDonald and others (2000).

Publishing support provided by

Lafayette Publishing Service Center

Information regarding water resources in Texas is available at

http://tx.usgs.gov/ 
